\title{
Supporting Information for \\ Natural Organic Matter (NOM) Imparts Molecular-Weight-Dependent Steric Stabilization or Electrostatic Destabilization to Ferrihydrite Nanoparticles
}

Zhixiong $\mathrm{Li}^{\dagger 1,2}$, Sheyda Shakiba ${ }^{\dagger 2}$, Ning Deng ${ }^{2}$, Jiawei Chen*1, Stacey M. Louie ${ }^{2 *}$, and Yandi $\mathrm{Hu}^{2 *}$

${ }^{1}$ State Key Laboratory of Biogeology \& Environmental Geology, China University of Geosciences, Beijing 100083, PR China

${ }^{2}$ Department of Civil \& Environmental Engineering, University of Houston, Houston, TX 77004, United States

$\dagger$ Equal Contribution

${ }^{*}$ Corresponding authors:

Phone and Fax: +86 10 8232678; Email: chenjiawei@,cugb.edu.cn

Phone: 713-743-8646; Fax: 713-743-4260; Email: $\underline{\text { slouie@uh.edu }}$

Phone: 713-743-4285; Fax: 713-743-4260; Email: yhu11@uh.edu

(Pages: 30, Tables: 2, Figures: 15) 


\section{Table of Contents}

1. Literature Review of Nanoparticle Aggregation with Molecular Weight-Fractionated

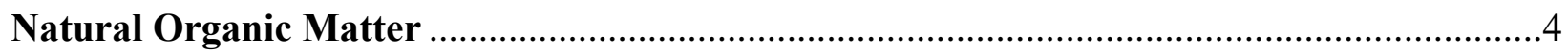

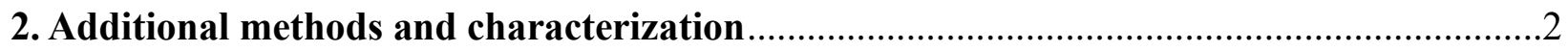

2.1. Characterization of synthesized ferrihydrite nanoparticles (Fh NPS)............................ 2

2.2. Preparation of Suwannee river natural organic matter (SRNOM) fractions .................. 5

2.3. Determining the critical coagulation concentration (CCC) of Fh NPs in the absence of

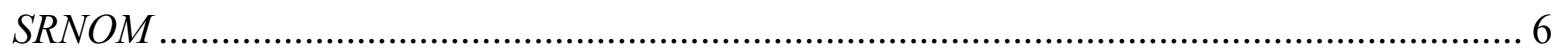

2.4. Obtaining the molecular weight $(M W)$ of SRNOM fractions by SEC............................ 7

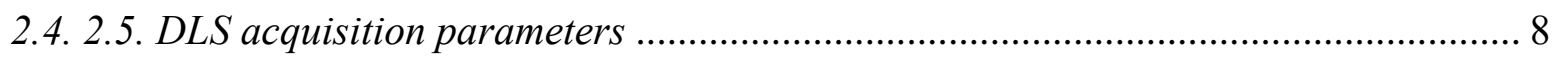

2.6. Size measurement conducted by single-particle inductively coupled plasma mass spectroscopy (spICP-MS) ........................................................................................... 9

2.7 Fractal dimension by static light scattering ………...................................................11

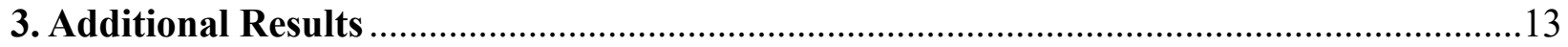

3.1. DLS scattering intensities from NOM with NPs ........................................................ 13

3.2. Characterization of fractionated SRNOM by SEC …………………………............ 14

3.3. Calculation of the number of different MW NOM molecules adsorbed on each Fh NP 17

3.4. Specific UV Absorbance (SUVA) of NOM fractions before and after adsorption ......... 18

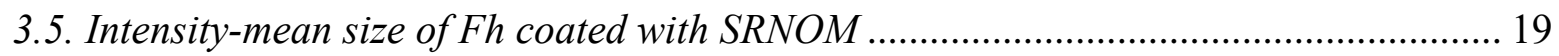

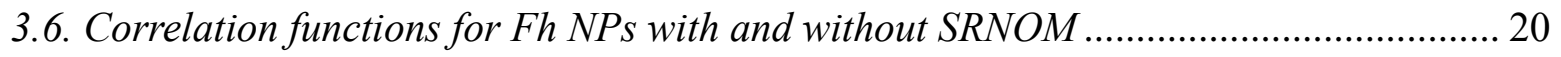

3.7. Zeta potentials of different fractions of NOM adsorbed to Fh NPs.............................. 21

3.8. NP aggregation and adsorbed mass with $S R N O M_{<3 k D a}$ at different $C / F e$ mass ratios .. 22

3.9. Determination of size for Fh NPs with spICP-MS..................................................... 24

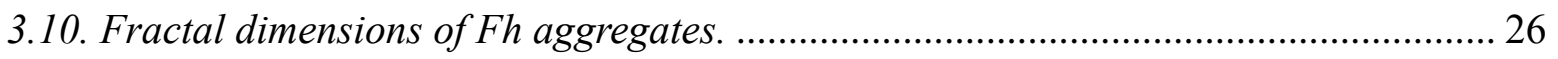

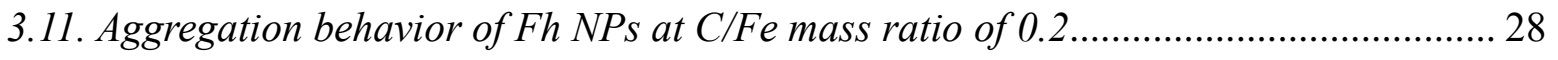

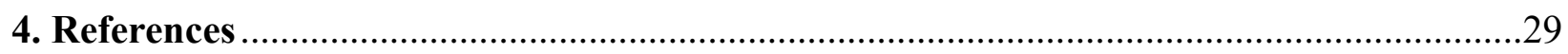

\section{Table of Figures}

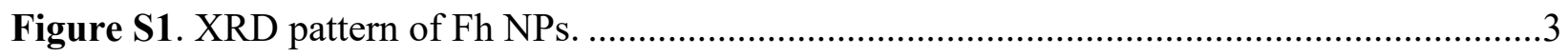

Figure S2. Zeta potential of Fh NPs at room temperature in the presence of $5 \mathrm{mM} \mathrm{NaNO}_{3} \ldots \ldots . .4$

Figure S3. Schematic showing preparation of SRNOM fractions ............................................

Figure S4. Aggregation kinetics of Fh NPs were measured by time-resolved DLS in varying

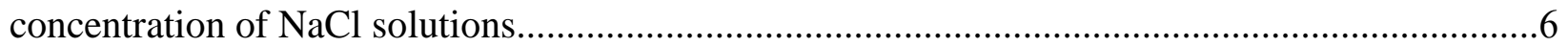

Figure S5. SEC-MALS results for SRNOM fractions.............................................................15 Figure S6. SEC-UV 280 chromatograms (a and c) and difference chromatograms (b and d) for SRNOM fractions before and after adsorption onto Fh NPs ....................................................16 Figure S7. SUVA at wavelengths of 254 and $280 \mathrm{~nm}$ for dissolved NOM fractions before and after adsorption onto ferrihydrite NPs .18 
Figure S8 Aggregation kinetic profiles plot as intensity-based diameter.

Figure S9. Correlation function of Fh NPs in DI water, and in solutions with or without different SRNOM fractions in $150 \mathrm{mM} \mathrm{NaCl}$ obtained after 15 minutes.

Figure S10. Zeta potentials of Fh NPs after adsorption of unfractionated and fractionated NOM at different $\mathrm{C} / \mathrm{Fe}$ ratios, $\mathrm{R}=1$ and 0.5 .

Figure S11. Fh NPs aggregation kinetic in $\mathrm{SRNOM}_{<3 \mathrm{kDa}}$ with different $\mathrm{C} / \mathrm{Fe}$ ratio in $150 \mathrm{mM} \mathrm{NaCl}$ $(\mathrm{pH}=5.5 \pm 0.2)$

Figure S12. Adsorbed mass for $\mathrm{SRNOM}_{<3 \mathrm{kDa}}$ with different $\mathrm{C} / \mathrm{Fe}$ ratios $(0.5,1,2)$ in $150 \mathrm{mM}$ $\mathrm{NaCl}(\mathrm{pH}=5.5 \pm 0.2)$. .23

Figure S13. Number-based particle size distributions of Fh NPs using spICP-MS.

Figure S14. Plot of log scattering intensities versus the log scattering vector to obtain the fractal dimensions of Fh NPs $(10 \mathrm{mg} \mathrm{Fe} / \mathrm{L})$ at $\mathrm{pH}=5.5 \pm 0.2$ in $\mathrm{NaCl}$ solution $(150 \mathrm{mM})$ in the absence of SRNOM and in the presence of $\mathrm{SRNOM}_{<3 \mathrm{kDa}}(10 \mathrm{mg} \mathrm{C} / \mathrm{L})$.

Figure S15. Aggregation kinetic of $\mathrm{Fh} \mathrm{NPs}$ at $\mathrm{pH}=5.5 \pm 0.2$ in $\mathrm{NaCl}$ solution $(150 \mathrm{mM})$ in the absence of SRNOM and in the presence of $\mathrm{SRNOM}_{10-30 \mathrm{kDa}}$ and $\mathrm{SRNOM}_{30-100 \mathrm{kDa}}$ at $\mathrm{C} / \mathrm{Fe}=0.2$...28

\section{Table of Tables}

Table S1. Summary of the effects of MW fractionated NOM on NP aggregation behavior..........2

Table S2. Comparison of NP or aggregate diameters derived from DLS. ................................25 


\section{Literature Review of Nanoparticle Aggregation with Molecular Weight-}

\section{Fractionated Natural Organic Matter}

Several papers have investigated the effect of molecular weight (MW)-fractionated natural organic matter (NOM) on the aggregation of engineered nanoparticles (NPs). In Table S1 below, we summarize the NP types, NOM fractionation, characterization methods, and main conclusions

from the prior literature to identify knowledge gaps, compare to the results of this research, and develop generalized conclusions on the major mechanisms by which NOM impacts NP aggregation. 
Table S1. Summary of the effects of MW-fractionated NOM on NP aggregation behavior

\begin{tabular}{|c|c|c|c|c|c|c|c|c|c|}
\hline Reference & NPs & $\begin{array}{l}\text { Initial } \\
\text { NP } \\
\text { coating }\end{array}$ & $\mathbf{p H}$ & $\begin{array}{l}\text { Initial } \\
\text { NP } \\
\text { charge }\end{array}$ & Electrolyte & $\begin{array}{l}\text { NOM } \\
\text { source }\end{array}$ & $\begin{array}{c}\text { NOM } \\
\text { fractions }\end{array}$ & $\begin{array}{l}\text { Characterization } \\
\text { methods }\end{array}$ & $\begin{array}{c}\text { Effect of } M W \text { fractions on } \\
\text { NP aggregation }\end{array}$ \\
\hline $\begin{array}{l}\text { Louie et } \\
\text { al. }(2013)^{1}\end{array}$ & Gold & Citrate & 8.3 & Negative & $\mathrm{NaCl}$ & $\begin{array}{l}\text { Suwannee } \\
\text { River } \\
\text { NOM } \\
\text { (SRNOM) }\end{array}$ & $\begin{array}{l}\text { Unfractionated } \\
\text { NOM, } \\
>100 \mathrm{kDa} \\
<100 \mathrm{kDa}\end{array}$ & $\begin{array}{l}\text { DLS, SEC, } \\
\text { fluorescence, } \\
\text { UV-vis, TEM }\end{array}$ & $\begin{array}{l}\text { Larger NOM fraction provided } \\
\text { better NP stability than } \\
\text { smaller fraction due to the } \\
\text { steric effects. }\end{array}$ \\
\hline $\begin{array}{l}\text { Louie et } \\
\text { al. }(2015)^{4}\end{array}$ & Gold & Citrate & 8.3 & Negative & $\mathrm{NaCl}$ & $\begin{array}{l}\text { Pahokee } \\
\text { Peat HA, } \\
\text { Suwannee } \\
\text { River HA, } \\
\text { Elliott } \\
\text { Soil FA, } \\
\text { Pony } \\
\text { Lake FA, } \\
\text { Pacific } \\
\text { Ocean FA }\end{array}$ & $\begin{array}{l}\text { Unfractionated } \\
\text { NOM, } \\
>100 \mathrm{kDa} \\
<100 \mathrm{kDa}\end{array}$ & $\begin{array}{l}\text { DLS, zeta- } \\
\text { potential, SEC, } \\
\text { fluorescence, } \\
\text { UV-vis }\end{array}$ & $\begin{array}{l}\text { 1. Generally, larger fraction } \\
\text { could provide better stability } \\
\text { than lower MW components } \\
\text { for each types of NOM. } \\
\text { 2. A synergistic effect between } \\
\text { high and low fractions could } \\
\text { be found to provide better } \\
\text { stabilization. } \\
\text { 3. Weight-averaged MW was } \\
\text { the best single explanatory } \\
\text { variable for NP aggregation } \\
\text { rates. }\end{array}$ \\
\hline $\begin{array}{l}\text { Shen et al. } \\
(2015)^{5}\end{array}$ & $\begin{array}{l}\text { Fullerene } \\
(\mathrm{nC} 60)\end{array}$ & $\begin{array}{l}\text { Without } \\
\text { coating }\end{array}$ & 7.5 & Negative & $\begin{array}{l}\mathrm{NaCl}, \\
\mathrm{CaCl}_{2} \\
\mathrm{MgCl}_{2}\end{array}$ & $\begin{array}{l}\text { Suwannee } \\
\text { River } \\
\text { NOM }\end{array}$ & $\begin{array}{l}\text { Unfractionated } \\
\text { NOM, } \\
>100 \mathrm{kDa} \text {, } \\
30-100 \mathrm{kDa}, \\
10-30 \mathrm{kDa}, \\
3-10 \mathrm{kDa}, \\
<3 \mathrm{kDa}\end{array}$ & $\begin{array}{l}\text { DLS, zeta- } \\
\text { potential, TEM, } \\
\text { UV-vis }\end{array}$ & $\begin{array}{l}\text { 1. Larger fractions of NOM } \\
\text { could provide better stability } \\
\text { in } \mathrm{NaCl} \text { due to the steric- } \\
\text { hindrance combined with } \\
\text { electrostatic effect. } \\
\text { 2. High MW SRNOM ( }>100 \\
\mathrm{kDa} \text { and } 30-100 \mathrm{kDa}) \\
\text { promoted aggregation at high } \\
\text { concentration of divalent } \\
\text { cations, especially in long } \\
\text { term aggregation because of } \\
\text { the bridging effect. }\end{array}$ \\
\hline
\end{tabular}


Table S1 (continued). Summary of the effects of MW-fractionated NOM on NP aggregation behavior

\begin{tabular}{|c|c|c|c|c|c|c|c|c|c|}
\hline Reference & NPs & $\begin{array}{l}\text { Initial NP } \\
\text { co-ating }\end{array}$ & pH & $\begin{array}{c}\text { Initial } \\
\text { NP } \\
\text { charge }\end{array}$ & Electrolyte & $\begin{array}{l}\text { NOM } \\
\text { source }\end{array}$ & $\begin{array}{l}\text { NOM } \\
\text { fractions }\end{array}$ & $\begin{array}{l}\text { Characteriza } \\
\text { tion methods }\end{array}$ & $\begin{array}{c}\text { Effect of MW fractions on } \\
\text { NP aggregation }\end{array}$ \\
\hline $\begin{array}{l}\text { Shen et al. } \\
(2019)^{3}\end{array}$ & $\begin{array}{c}\text { Graphene } \\
\text { oxide } \\
\text { (GO) }\end{array}$ & $\begin{array}{l}\text { Without } \\
\text { coating }\end{array}$ & 7.5 & Negative & $\begin{array}{l}\mathrm{NaCl}, \\
\mathrm{CaCl}_{2}\end{array}$ & $\begin{array}{l}\text { Suwannee } \\
\text { River } \\
\text { NOM }\end{array}$ & $\begin{array}{l}\text { Unfractionated } \\
\text { NOM, } \\
>100 \mathrm{kDa} \text {, } \\
30-100 \mathrm{kDa} \text {, } \\
10-30 \mathrm{kDa} \text {, } \\
3-10 \mathrm{kDa} \text {, } \\
<3 \mathrm{kDa}\end{array}$ & $\begin{array}{l}\text { DLS, zeta } \\
\text { potential, } \\
\text { TEM, XPS }\end{array}$ & $\begin{array}{l}\text { Larger fractions of NOM } \\
\text { could provide better stability } \\
\text { in } \mathrm{NaCl} \text { due to the steric- } \\
\text { hindrance effect. }\end{array}$ \\
\hline $\begin{array}{l}\text { Zhou et al. } \\
(2019)^{6}\end{array}$ & $\begin{array}{c}\text { Graphene } \\
\text { oxide } \\
\text { (GO) }\end{array}$ & $\begin{array}{l}\text { Without } \\
\text { coating }\end{array}$ & 7 & $\begin{array}{l}\text { Not } \\
\text { reported }\end{array}$ & Without salt & HA & $\begin{array}{l}\text { Unfractionated } \\
\text { NOM, } \\
>30 \mathrm{kDa} \\
10-30 \mathrm{kDa} \\
3-10 \mathrm{kDa} \\
<3 \mathrm{kDa}\end{array}$ & $\begin{array}{l}\text { DLS, FTIR, } \\
\text { UV-vis }\end{array}$ & $\begin{array}{l}\text { GO aggregation was } \\
\text { negatively correlated with the } \\
\text { MW of HA, probably because } \\
\text { the high content of aromatic } \\
\text { rings in the large fraction can } \\
\text { cause a high steric repulsion. }\end{array}$ \\
\hline
\end{tabular}




\section{Additional Methods and Characterization}

\subsection{Synthesis and characterization of ferrihydrite nanoparticles (Fh NPs)}

The Fh NP synthesis was modified from the procedure by Tang et al. ${ }^{7}$ Briefly, to attain a total iron concentration of $0.1 \mathrm{M} \mathrm{Fe}, 4.04 \mathrm{~g}$ of Fe$\left(\mathrm{NO}_{3}\right)_{3} \cdot 9 \mathrm{H}_{2} \mathrm{O}$ was dissolved in $100 \mathrm{~mL}$ deionized (DI) water $(18.2 \mathrm{M} \Omega \cdot \mathrm{cm})$. Then, $\mathrm{NaOH}(1 \mathrm{M})$ was slowly added to the solution at room temperature via a syringe pump $(0.5 \mathrm{~mL} / \mathrm{min})$ to obtain a final $\mathrm{pH}$ of $3.0 \pm 0.1$. During $\mathrm{Fe}$ hydrolysis and precipitation, the solution was vigorously mixed by a magnetic stirrer. After reaching the desired $\mathrm{pH}$, the solution was mixed for another hour. Finally, the solution was filtered through $0.2 \mu \mathrm{m}$ polyethersulfone (PES) filters (EMD Millipore, Burlington, MA). The particles collected on filters were re-dispersed in acidic water (adjusted to $\mathrm{pH}=3$ with $\mathrm{HNO}_{3}$ ), followed by 60 min bath sonication (Branson 1800, Emerson, St. Louis, MO). The stock suspension of NPs were stored at $4{ }^{\circ} \mathrm{C}$.

X-ray diffraction (XRD) was conducted to characterize the crystallinity of the synthesized NPs (Figure S1). Two broad diffraction peaks showed up at $2 \theta$ of $35^{\circ}$ and $63^{\circ}$, indicating that these sysnthesized NPs were 2-line ferrihydrite. ${ }^{8}$ 


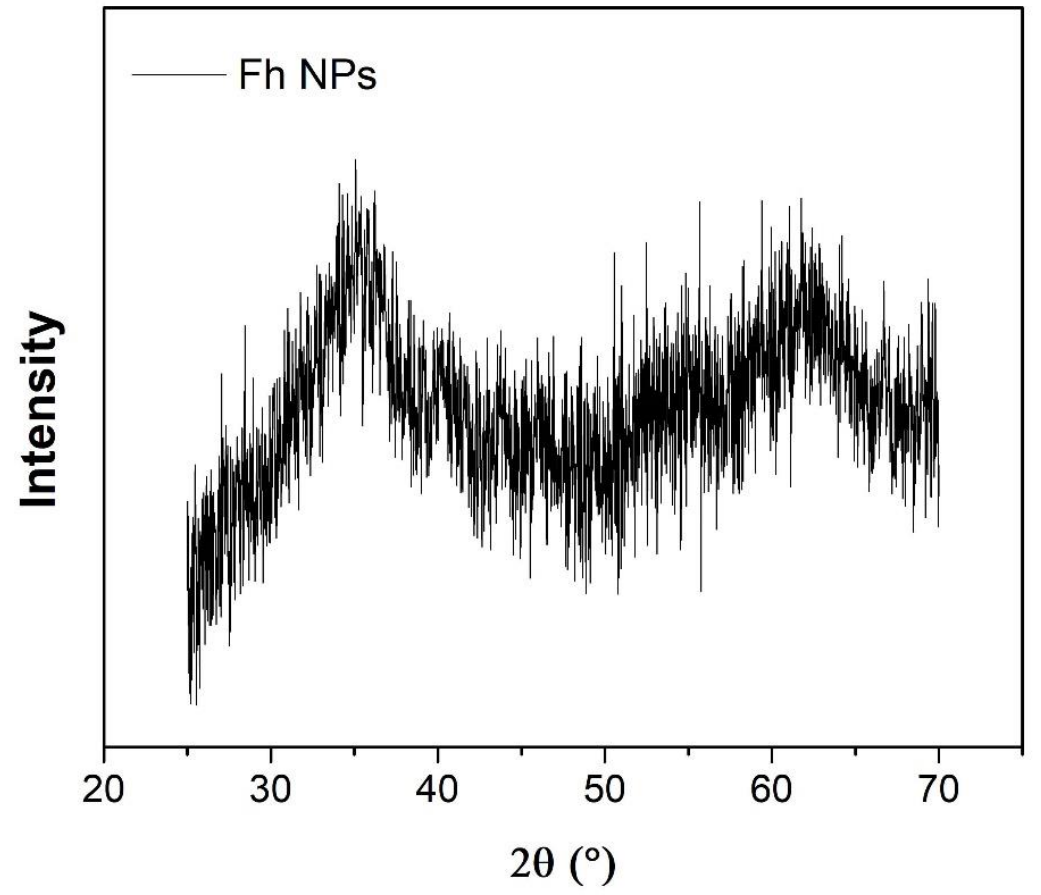

Figure S1. XRD pattern of Fh NPs. 
Electrophoretic light scattering was utilized to identify the $\mathrm{pH}$ isoelectric point $\left(\mathrm{pH}_{\mathrm{iep}}\right)$ of the synthesized Fh NPs. Figure S2 shows the zeta potential of Fh NPs in the presence of $\mathrm{NaNO}_{3}$ solution $(5 \mathrm{mM})$ across different $\mathrm{pH}$. The $\mathrm{pH}_{\text {iep }}$ of the Fh NPs is determined to be 7.1 , consistent with previous studies. ${ }^{9,}, 10$

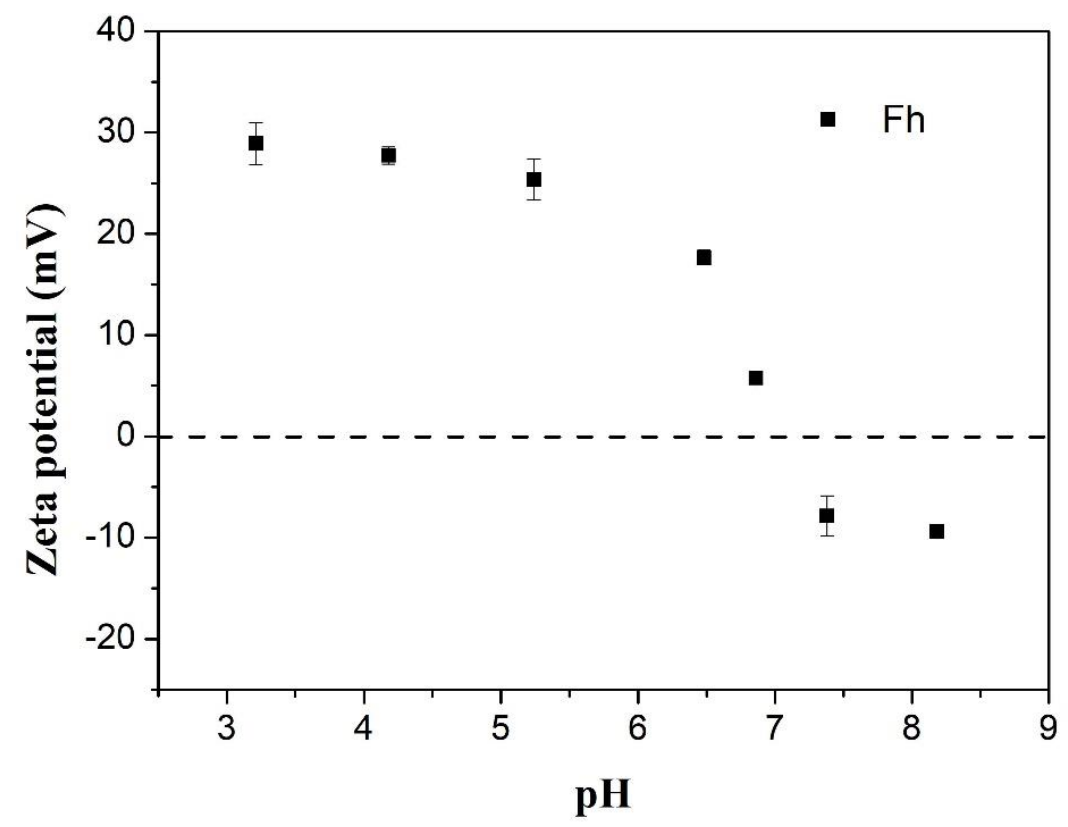

Figure S2. Zeta potential of Fh NPs at room temperature in the presence of $5 \mathrm{mM} \mathrm{NaNO}$.

Error bars represent the standard deviation across $n=3$ samples. 


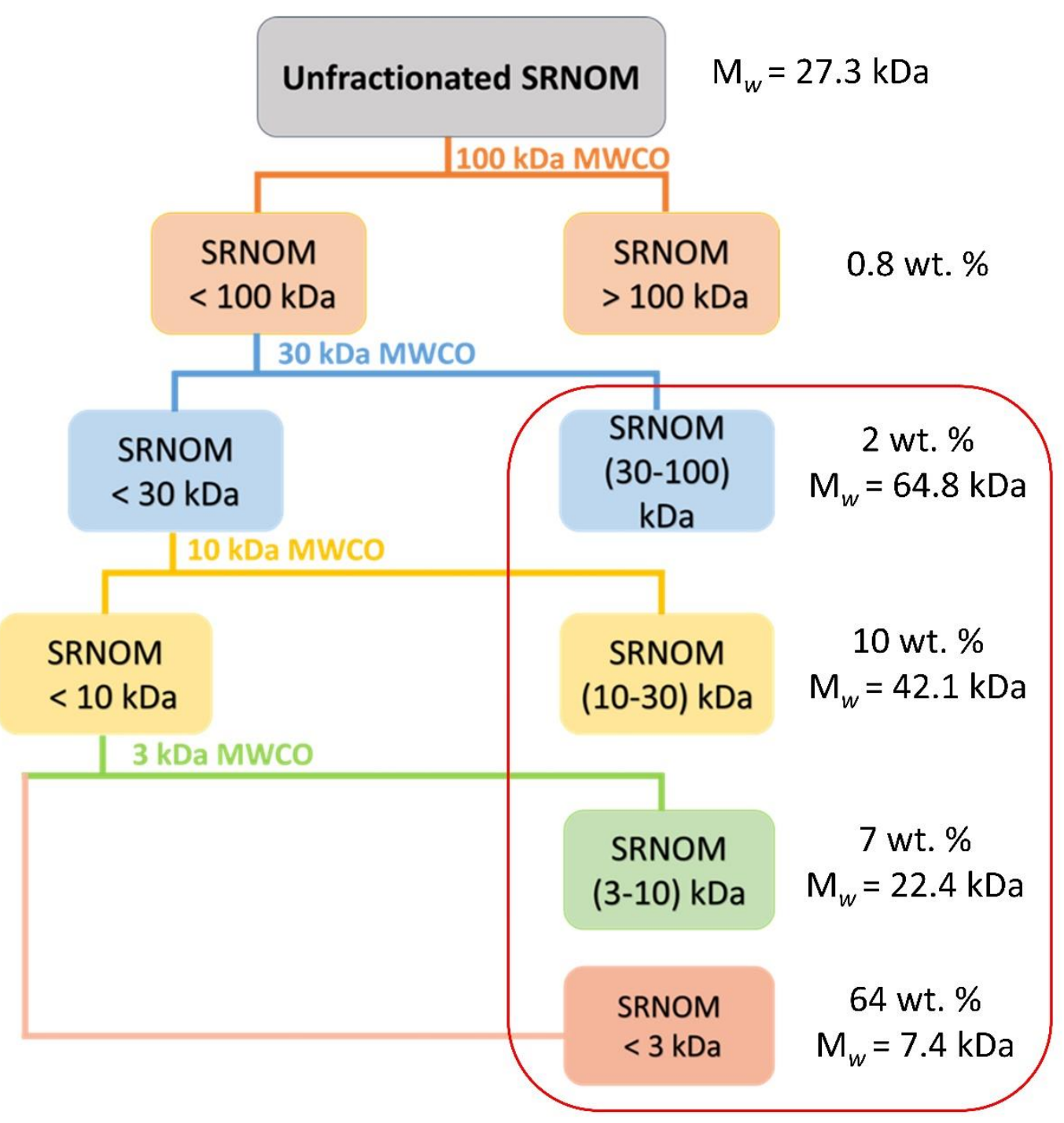

Figure S3. Schematic showing preparation of SRNOM fractions. 
2.3. Determining the critical coagulation concentration (CCC) of Fh NPs in the absence of SRNOM

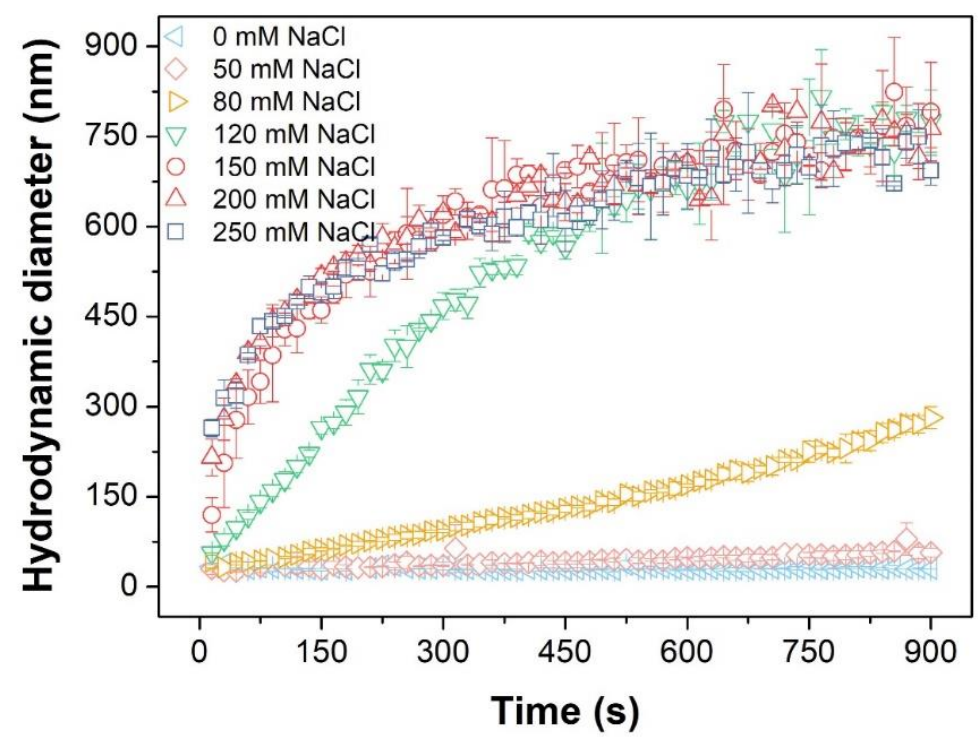

Figure S4. Aggregation kinetics of Fh NPs were measured by time-resolved dynamic light scattering (DLS) on $10 \mathrm{mg} / \mathrm{L}$ as $\mathrm{Fe}$ in varying concentration of $\mathrm{NaCl}$ solutions ((0 to 250$) \mathrm{mM}$ ) in the absence of SRNOM at $\mathrm{pH}=5.5 \pm 0.2$. Error bars represent the standard deviation for $n$ $=2$ samples. 
2.4. Obtaining the MW of SRNOM fractions by size exclusion chromatography (SEC)

The weight-average molecular weight $\left(M_{\mathrm{w}}\right)$ at each chromatographic time point by SEC was obtained by using Wyatt ASTRA software (7.1.2.5) using the Zimm equation (eq S1):

$$
\frac{K c}{\Delta R(\theta, c)}=\frac{1}{M_{\mathrm{w}} P(\theta)}+2 A_{2} c=\frac{1}{M_{\mathrm{w}}}\left(1+\frac{q^{2} R_{\mathrm{g}}^{2}}{3}\right)+2 A_{2} C
$$

where $K$ is an optical constant $\left(1.31 \times 10^{-11} \mathrm{~mol}^{2} \mathrm{~m}^{2} \mathrm{~g}^{-2}\right), \Delta R(\theta, c)$ is the measured Rayleigh ratio (the ratio of the excess scattering intensity for the solute to the solvent per unit volume) as a function of scattering angle $\theta$ and measured mass concentration $c, P(\theta)$ is the shape factor. $A_{2}$ is the second virial coefficient (assumed to be 0 ), $R_{\mathrm{g}}$ is the radius of gyration, and $q$ is the scattering vector. The instrument contains 16 detectors at various angles, which enable it to measure the scattering intensity at different angles simultaneously. Louie et al. have thoroughly discussed advantages and limitations of this method of MW determination. ${ }^{4}$ In brief, the mass concentration of the analyte can be obtained by using either a differential refractive index (dRI) or UV detector. In this study, the dRI detector was chosen as the source to obtain the concentration with the refractive index increment $(\mathrm{d} n / \mathrm{d} c)$ value set to $0.146(\mathrm{~mL} / \mathrm{g}),{ }^{11}$ considering that all fractions of the NOM do not have the same UV extinction coefficient. Therefore, the dRI detector is taken to be a more universal detector than the UV detector. However, use of this detector also has limitations, including the assumption that all fractions of NOM have the same $\mathrm{d} n / \mathrm{d} c$ value and the presence of a negative dRI peak at the end of the chromatogram due to elution of the solvent from the column. Overall, given the concentration and MW at each chromatographic time point, the mean $M_{\mathrm{w}}$ across the entire NOM peak can be computed. 


\subsection{DLS acquisition parameters}

Multiple scattering effects may occur for high concentrations of nanoparticles or large aggregates that can affect the DLS data. Here, we note that the starting concentration of nanoparticles was low (10 mg/L), such that the Malvern Zetasizer Software (v. 7.13) determined an optimum attenuator setting of " 11 " (i.e., the widest aperture) for the unaggregated particles in DI water, indicating low scattering intensity. For the Fh NPs aggregating rapidly in $150 \mathrm{mM} \mathrm{NaCl}$, the optimum attenuation was 8 to 9 , still indicating relatively low scattering intensities (minimum attenuator setting possible is 1). To minimize the duration and variability in the delay time between mixing and sample measurement, we applied the same attenuation and measurement position to all samples rather than re-optimizing on each measurement. Since we are primarily interested in the early stage aggregation, the settings for the unaggregated particles were applied consistently across all samples. While it is still possible that multiple scattering can influence late time point measurements for highly aggregated samples (resulting in lower apparent sizes), the initial stage aggregation measurements and major qualitative trends observed and discussed (i.e., more rapid or less rapid aggregation) should be reliable. 


\subsection{Size measurement conducted by single-particle inductively coupled plasma mass spectroscopy}

(spICP-MS)

To better discern the fractal structure of the aggregates, the Fe amount in each aggregate was evaluated by spICP-MS. The operation parameters were conducted at a dwell time of $100 \mu \mathrm{s}$, a settling time of $0 \mu \mathrm{s}$ and a total acquisition time of $30 \mathrm{~s}$. Before each analysis, the sample flow rate was measured by weighing the mass changes of ultrapure water uptake into the peristaltic pump for $10-15 \mathrm{~min}$ at a flow rate of $0.38 \pm 0.1 \mathrm{~mL} / \mathrm{min}$.

The calibration for spICP-MS measurement was achieved by analysis of dissolved iron solutions and the nebulizer transport efficiency (mass transfer through the nebulizer/ spray chamber system). ${ }^{12-14}$ The need for determining the transport efficiency arises from the different mass transport through the nebulizer/ spray chamber system for an individual nanoparticle and dissolved ions. ${ }^{13-15}$ The intensity of ionic ions depends on the transport efficiency, while the intensity of an individual NP is not, which is only related to the particle size. The nebulizer transport efficiency was determined for each analysis based on the "particle size method" using reference Au NPs (with a nominal diameter of $30 \mathrm{~nm}$; BBI Solutions, Crumlin, UK) and ionic $\mathrm{Au}$ standards (at concentrations of $0.1-10 \mu \mathrm{g} / \mathrm{L}$; Sigma Aldrich, St. Louis, MO). ${ }^{13,14,16-19}$ Briefly, the "particle size method" utilizes the ratio of solution sensitivity to the particle sensitivity to determine the nebulizer transport efficiency. The first step requires generating a calibration curve of the intensity (cps) versus the concentrations of the ionic Au standards $(\mu \mathrm{g} / \mathrm{L}) .{ }^{14,16,19}$ The second step is to calculate the total mass $(\mu \mathrm{g})$ of $\mathrm{Au}$ in each ionic Au standard solution entering the sample introduction system, which can be obtained by multiplying each ionic Au standard concentration $(\mu \mathrm{g} / \mathrm{L})$ by the sample flow rate $(\mathrm{mL} / \mathrm{min})$ and the dwell time $(\mu \mathrm{s}){ }^{16,18,19}$ Third, a second calibration curve of the intensity (cps) versus the total mass of ionic Au in the standard solutions $(\mu \mathrm{g})$ entering the sample introduction system can be created from the first two steps, and the slope of the second calibration curve is the solution sensitivity (cps/ $\mu \mathrm{g}) .{ }^{13,14,16}$ Fourth, the particle sensitivity (cps/ $\mu \mathrm{g}$ ) can be calculated by dividing the intensity (cps) of reference Au NPs of a known particle size with 
the mass of the reference Au NPs, which can be easily calculated using the diameter and the density of the reference Au NPs. ${ }^{14,} 16$ The intensity of ionic Au standards depends on the transport efficiency, while the intensity of an individual Au NP is only related to the particle size. ${ }^{14,16,18}$ Therefore, the transport efficiency was determined using the ratio of solution sensitivity to particle sensitivity. For this study, the transport efficiency was measured between 15 and $17 \%$.

All data were collected and analyzed using the Qtegra software (Version 2.10 SR1, Thermo Scientific). Particle events were distinguished from the background (dissolved ions) using a $3 \sigma$ criterion during the data analysis. ${ }^{13,16,20}$ The frequency of the spikes is directly associated with the Fh particle concentration (particles $/ \mathrm{mL}$ ) and the signal intensity of each spike is proportional to the mass of $\mathrm{Fe}$ in the Fh particle $\left(M_{\mathrm{NP}}, \mathrm{g}\right)$, which can be converted to the Fh particle diameter $(D$, $\mathrm{nm})$ with the assumption of a spherical geometry using the mass fraction of $\mathrm{Fe}$ in $\mathrm{Fh} \mathrm{NP}\left(f_{\mathrm{a}}, \%\right)$ and density $\left(\rho, \mathrm{g} / \mathrm{cm}^{3}\right)$ of Fh particle, according to eq S2:

$$
D=\sqrt[3]{\frac{6 M_{\mathrm{NP}}}{\rho \pi}}=\sqrt[3]{\frac{6 \eta I_{\mathrm{NP}}}{K f_{\mathrm{a}} \rho \pi}}
$$

where $D(\mathrm{~nm})$ and $\rho\left(\mathrm{g} / \mathrm{cm}^{3}\right)$ are the diameter and density of the Fh NPs; $M_{\mathrm{NP}}(\mathrm{g})$ is the mass of Fe in Fh NPs measured by spICP-MS; $\eta(\%)$ is the nebulizer transport efficiency; $I_{\mathrm{NP}}(\mathrm{cps})$ is the signal intensity of Fh NPs; $K$ (cps/g) is the slope of the calibration curve of Fe ion standards solution; $f_{\mathrm{a}}$ is the mass fraction of $\mathrm{Fe}$ in the Fh NP with the chemical form of $\mathrm{Fe}_{2} \mathrm{O}_{3} \cdot 2.5 \mathrm{H}_{2} \mathrm{O}$ for $\mathrm{Fh}^{7,21}$; Detailed derivation of eq S2 can be found in the work published by Pace. ${ }^{16}$ Based on the particle size distribution measured by spICP-MS, the average particle diameter is evaluated by fitting the size distribution data with lognormal distribution model. 


\subsection{Fractal dimension by static light scattering}

Fractal dimension $\left(d_{\mathrm{f}}\right)$ was determined on a Wyatt DAWN HELEOS II multi-angle light scattering (MALS) detector by batch injection of the nanoparticles into the MALS flow cell. The scattering intensities were detected at scattering angles of $37.5^{\circ}, 44.8^{\circ}, 53.1^{\circ}, 61.1^{\circ}, 70.1^{\circ}, 80.1^{\circ}$, $90^{\circ}, 99.9^{\circ}, 109.9^{\circ}, 120.1^{\circ}, 130.4^{\circ}$. All the detectors were normalized using bovine serum albumin (BSA) monomer as an isotropic scatterer to normalize scattering intensities at different angles. The scattering vectors were calculated using equation S3:

$$
q=\frac{4 \pi n}{\lambda} \sin \left(\frac{\Theta}{2}\right)
$$

In this equation, $q, n, \lambda$, and $\theta$ correspond to the scattering vector, solvent index of refraction (1.33 for water), vacuum wavelength of the incident light $(660 \mathrm{~nm})$, and the scattering angles, respectively. We restricted the use of scattering angles to those where $1 / R<q<1 / r_{0},{ }^{22}$ where $R$ is the radius of gyration of the aggregates and $r_{0}$ is the radius of the primary particles (here, taken as the $z$-average hydrodynamic radius from dynamic light scattering, $\approx 16 \mathrm{~nm}$ ). The unaggregated nanoparticles are too small to be analyzed within the $q$ range of the detectors (largest $q$ available of $0.023 \mathrm{~nm}^{-1}$ ). As we are primarily interested in the structure of the aggregates formed with the < $3 \mathrm{kDa} \mathrm{NOM}$ (that enhanced the aggregation rate in $150 \mathrm{mM} \mathrm{NaCl}$ ), the fractal dimensions of the aggregates of the uncoated nanoparticles and those with $<3 \mathrm{kDa}$ NOM (both in $150 \mathrm{mM} \mathrm{NaCl}$ ) were compared. For these aggregates, the full range of $q$ on our MALS instrument satisfies the requirement for $1 / R<q<1 / r_{0}$, but further restrictions were also made to exclude low-angle detectors with saturated scattered light intensities.

The samples were prepared following the same procedure as the aggregation and adsorption experiments and measured from $\approx 15$ to 30 min after mixing. The fractal dimension was obtained from the slope of a $\log$ scattering intensity vs. $\log q$. (Figure S14). Measurements were acquired every $2 \mathrm{~s}$ over a duration of $\approx 10$ minutes, and the average fractal dimension over 
the measurement duration for the sample without $\mathrm{SRNOM}$ and containing $\mathrm{SRNOM}_{<3 \mathrm{kDa}}$ was reported. 


\section{Additional Results}

\subsection{DLS scattering intensities from NOM with NPS}

NOM may also potentially form aggregates that could affect the DLS measurements. For example, Osterberg et al. investigated soil humic acid aggregates using small angle neutron scattering and found the radii of gyration to be 20 to $30 \mathrm{~nm}$, the $\mathrm{MW}$ from 500 to $2000 \mathrm{kDa}{ }^{23}$ They also concluded that humic acids ( 1 to $4 \mathrm{~g} / \mathrm{L}, \mathrm{pH} 5, I=0.1 \mathrm{M}$ ) could form clusters with fractal dimension of around 2.3. ${ }^{24}$ During another study, they observed that soil humic acids ( $\mathrm{pH} 5,0.1$ $\mathrm{M} \mathrm{NaCl}$ ) with smaller clusters formed a gel after storage in $4{ }^{\circ} \mathrm{C}$ and cluster-cluster interactions were investigated. ${ }^{25}$

The NOM in this study is an aquatic Suwannee River natural organic matter extract that is less likely to contain large aggregates than soil humic acids. Still, it is important to consider the potential for aggregation of NOM to contribute to the DLS results. For example, Xu et al. have investigated the effect of different ions on the aggregation of aquatic natural organic matter by using DLS and reported no significant aggregation of SRNOM (20 mg/L) in solutions containing monovalent cations (e.g., $300 \mathrm{mM} \mathrm{NaCl}$ ), while aggregation in solutions containing divalent cations could occur. ${ }^{26}$ Here, we also tried to obtain DLS measurements for SRNOM fractions in the media containing $150 \mathrm{mM} \mathrm{NaCl}$ (with no NPs). However, the obtained derived count rates for these DLS measurements with attenuator set to the widest aperture were $\approx 200 \mathrm{kcps}$, which was similar to that for DI water ( $\approx 190 \mathrm{kcps})$. In comparison, the count rates for aggregating NPs containing 10 ppm Fh NPs and $150 \mathrm{mM} \mathrm{NaCl}$ were $>4000 \mathrm{kcps}$. Therefore, we can conclude that the light scattering of the SRNOM is close to the background scattering in the system and not significant relative to the aggregating NPs, so the DLS results as reported in Figure 3 represent the aggregation of the NPs themselves rather than NOM. 


\subsection{Characterization of fractionated SRNOM by SEC}

The stock NOM fractions were analyzed by SEC-MALS to obtain MW distributions and mean weight-average molecular weights $\left(M_{\mathrm{w}}\right)$. As shown in Figure S5, the chromatograms show reasonably good separation of the fractions.

The weight-average molecular weights $\left(M_{\mathrm{w}}\right)$ of each fractionated NOM stock solution were determined in the Wyatt ASTRA software (7.1.2.5) across the quantifiable range in the LS signal (Table 1). The elution time was chosen starting from limit of quantification (LOQ) of raw dRI signal to end of the SRNOM fractionated peak. LOQ for each fractions was obtained by considering the average $(\mu)$ and standard deviation $(\sigma)$ of baseline noise of dRI signal from 0 to 10 minutes elution time for each fraction and starting at dRI signal $>\mu+10 \sigma$. If the negative solvent peak (elution time $\approx 30 \mathrm{~min}$ ) eluted prior to the complete elution of NOM, the end point for analysis was chosen as the elution time of the solvent. The considered elution times for SRNOM $\mathrm{Mnfractionated}_{\text {, }}$ $\mathrm{SRNOM}_{<3 \mathrm{kDa}}, \mathrm{SRNOM}_{3-10 \mathrm{kDa}}, \mathrm{SRNOM}_{10-30 \mathrm{kDa}}$, and $\mathrm{SRNOM}_{30-100 \mathrm{kDa}}$ were 17-30 min, 17-21 min, 16-20 min, 19.4-28 min, and 15.4-26 min, respectively. As shown in Table 1, the general trends in the average $M_{\mathrm{w}}$ measured by SEC-MALS match that of the nominal molecular weight cut-offs (MWCOs) reported by Amicon, while the measured absolute $M_{\mathrm{w}}$ values were higher than the upper MWCOs except for $\mathrm{SRNOM}_{30-100 \mathrm{kDa}}$. Egeberg et al. similarly reported that the molecular weights of various types of NOM estimated by ultrafiltration MWCOs were generally, but not always, lower than those measured by SEC-MALS. ${ }^{27}$ One reason for this difference might be the fact that the reported MWCO of the filters are estimated using proteins, which likely have a different conformation than NOM. ${ }^{28}$ In addition, the SEC-MALS method can overestimate the mean MW because of incomplete separation and co-elution of higher MW NOM over lower MW NOM, with the larger molecules more strongly influencing the MALS results, and also because any small NOM co-eluting with the negative dRI solvent peak are excluded from the $M_{\mathrm{w}}$ analysis. ${ }^{4}$ 
(a)
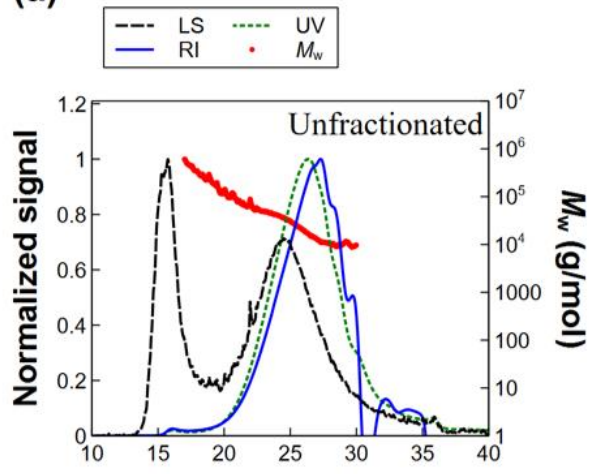

Elution time ( $\mathrm{min})$

(b)
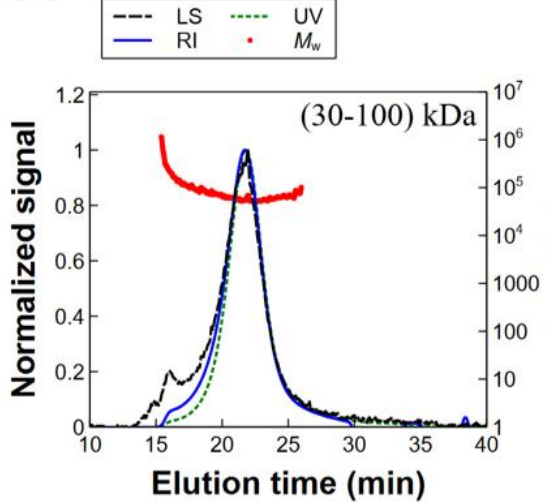

(c)

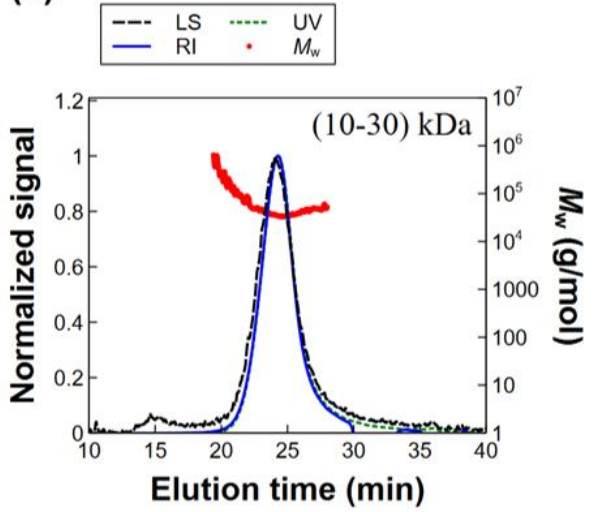

(d)

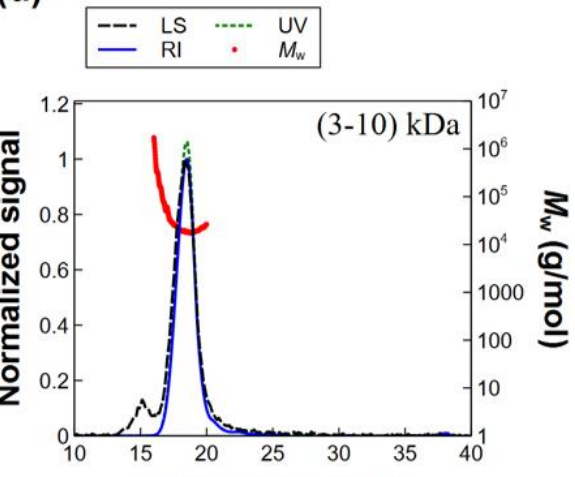

Elution time ( $\mathrm{min})$

(e)

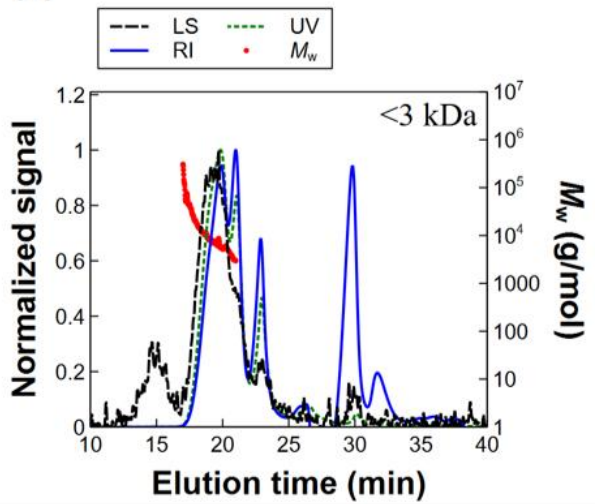

Figure S5. SEC-MALS results for SRNOM fractions. All RI, LS and $\mathrm{UV}_{280}$ signals are normalized to the value at peak maximum. $M_{\mathrm{w}}$ was obtained using MALS with RI as the concentration source. The mobile phase for the unfractionated NOM and higher MW NOM fractions $(>10 \mathrm{kDa})$ was $4 \mathrm{mM}$ phosphate buffer $(\mathrm{pH} 7)+25 \mathrm{mM} \mathrm{NaCl}$, while the lower $\mathrm{MW}$ fractions $(<10 \mathrm{kDa})$ were analyzed in $2 \mathrm{mM}$ phosphate buffer $(\mathrm{pH} 7)$. 

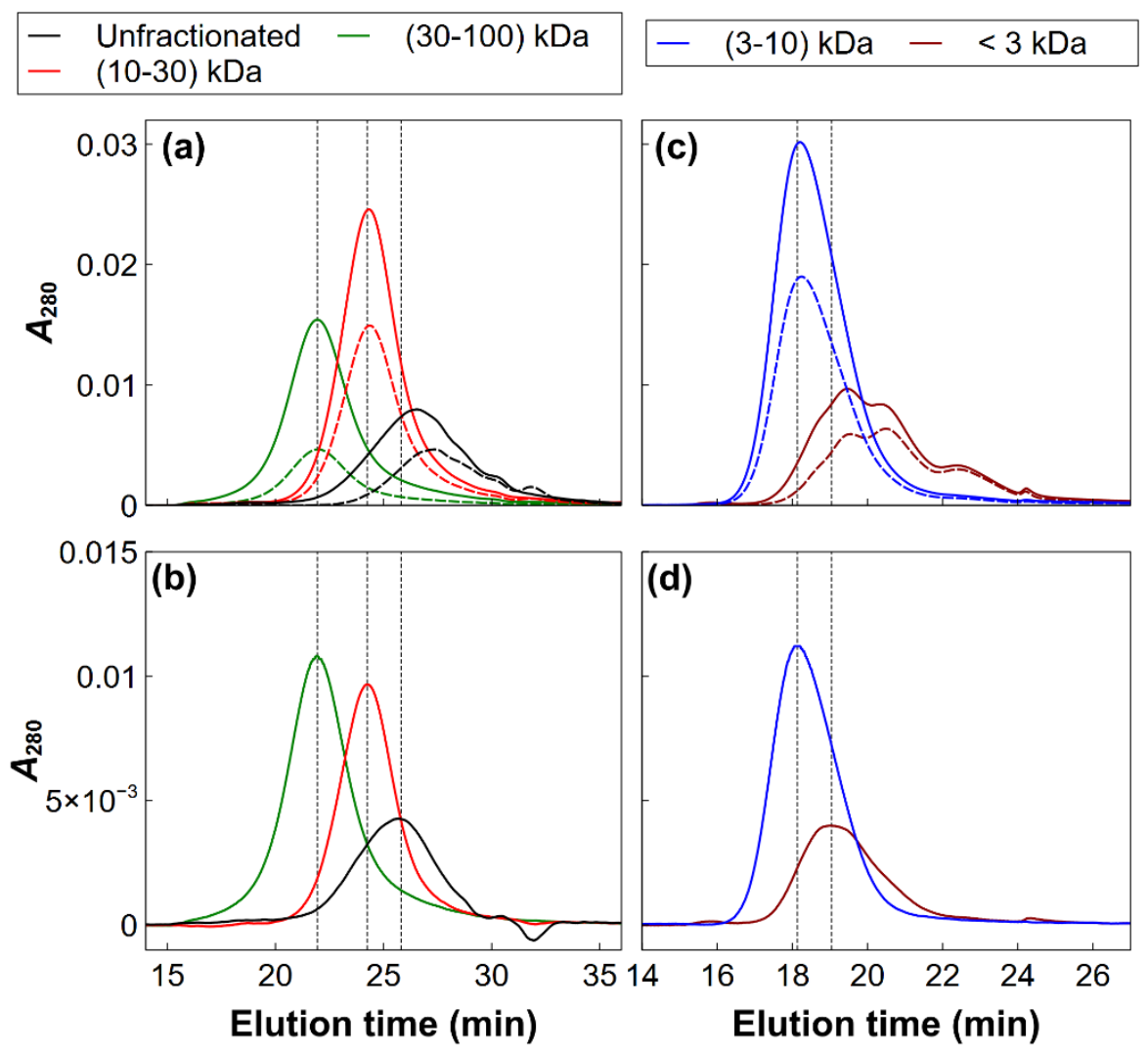

Figure S6. SEC-UV 280 chromatograms (a and c) and difference chromatograms (b and d) for SRNOM fractions before and after adsorption onto Fh NPs, to investigate the adsorbed species from the NOM solutions to NPs. "After adsorption" (dashed lines in (a) and (c)) chromatograms were obtained for the unadsorbed NOM collected as the filtrate from Amicon $100 \mathrm{kDa}$ centrifugal ultrafiltration devices for mixtures containing NOM (initially $10 \mathrm{mg} \mathrm{C} / \mathrm{L}), \mathrm{NaCl}(150 \mathrm{mM})$ and Fh NPs (10 mg Fe/L). "Before adsorption" chromatograms were obtained from control solutions containing no NPs and processed the same way. $\mathrm{UV}_{280}$ difference chromatograms ( $b$ and $d$ ) for all fractions were plotted by subtracting the SEC$\mathrm{UV}_{280}$ chromatograms for the NOM fractions after adsorption from before adsorption chromatograms, and represents the adsorbed species from the SRNOM fractions. The vertical dash lines show the peak location for each difference chromatogram. The mobile phase for the unfractionated NOM and higher MW NOM fractions ( $>10 \mathrm{kDa})$ was $4 \mathrm{mM}$ phosphate buffer $(\mathrm{pH} \mathrm{7})+25 \mathrm{mM} \mathrm{NaCl}$, while the lower MW fractions $(<10 \mathrm{kDa})$ were analyzed in $2 \mathrm{mM}$ phosphate buffer ( $\mathrm{pH} 7)$. 


\subsection{Calculation of the number of different MW NOM molecules adsorbed on each Fh NP}

The number concentrations of NPs and adsorbed NOM molecules were calculated based on the adsorption experiments. The number concentration of NPs $\left(\mathrm{N}_{\mathrm{Fh}}\right)$ was calculated using eq S4:

$$
N_{\mathrm{Fh}}=\frac{C_{\mathrm{Fh}}}{\rho_{\mathrm{Fh}}\left(\frac{4}{3} \pi r^{3}\right)}
$$

where $C_{\mathrm{Fh}}(\mathrm{g} / \mathrm{L})$ is the concenration of Fh NPs $(18.3 \mathrm{mg} / \mathrm{L})$, which is calculated from the Fe concentration $(10 \mathrm{mg} \mathrm{Fe} / \mathrm{L})$ and molar mass of ferrihydrite $\left(205 \mathrm{~g} / \mathrm{mol}\right.$, formula: $\left.\mathrm{Fe}_{2} \mathrm{O}_{3} \cdot 2.5 \mathrm{H}_{2} \mathrm{O}\right){ }^{7}$ $\rho\left(\mathrm{g} / \mathrm{cm}^{3}\right)$ is the density of Fh, which is $3.8 \mathrm{~g} / \mathrm{cm}^{3.29}$ and $r(\mathrm{~cm})$ is the radius of Fh NPs which is 15 $\mathrm{nm}$ from dynamic light scattering (DLS) measurement.

The number concentration of adsorbed NOM $\left(N_{\mathrm{NOM}}\right)$ molecules were calculated using eq S5:

$$
N_{\mathrm{NOM}}=\frac{C_{\mathrm{NOM}}}{M_{\mathrm{w}}} \mathrm{N}_{\mathrm{A}}
$$

where $C_{\mathrm{NOM}}(\mathrm{g} / \mathrm{L})$ is the mass concentration of adsorbed NOM, which is derived from TOC measurements. We assumed that all fractions have approximately the same $\%$ carbon as the overall NOM to calculate total mass from carbon concentration. The measured percentage of carbon in unfractionated NOM was $40 \% ; \mathrm{N}_{\mathrm{A}}$ is the Avogadro constant, $6.02 \times 10^{23}$; and $M_{\mathrm{w}}(\mathrm{g} / \mathrm{mol})$ is the weight-average molecular weight of adsorbed NOM fractions at the peak maximum (Table 1). Since the adsorbed species do not necessarily have the same $M_{\mathrm{w}}$ as the overall NOM fraction, we used the peak $M_{\mathrm{w}}$ of the adsorbed species identified in the SEC difference chromatograms (Figure S6, Table 1) rather than that of the bulk NOM.

Finally the number of NOM molecules adsorbed on each Fh NP were calculated by dividing $N_{\mathrm{NOM}}$ by $N_{\mathrm{Fh}}$ for each fractions. 


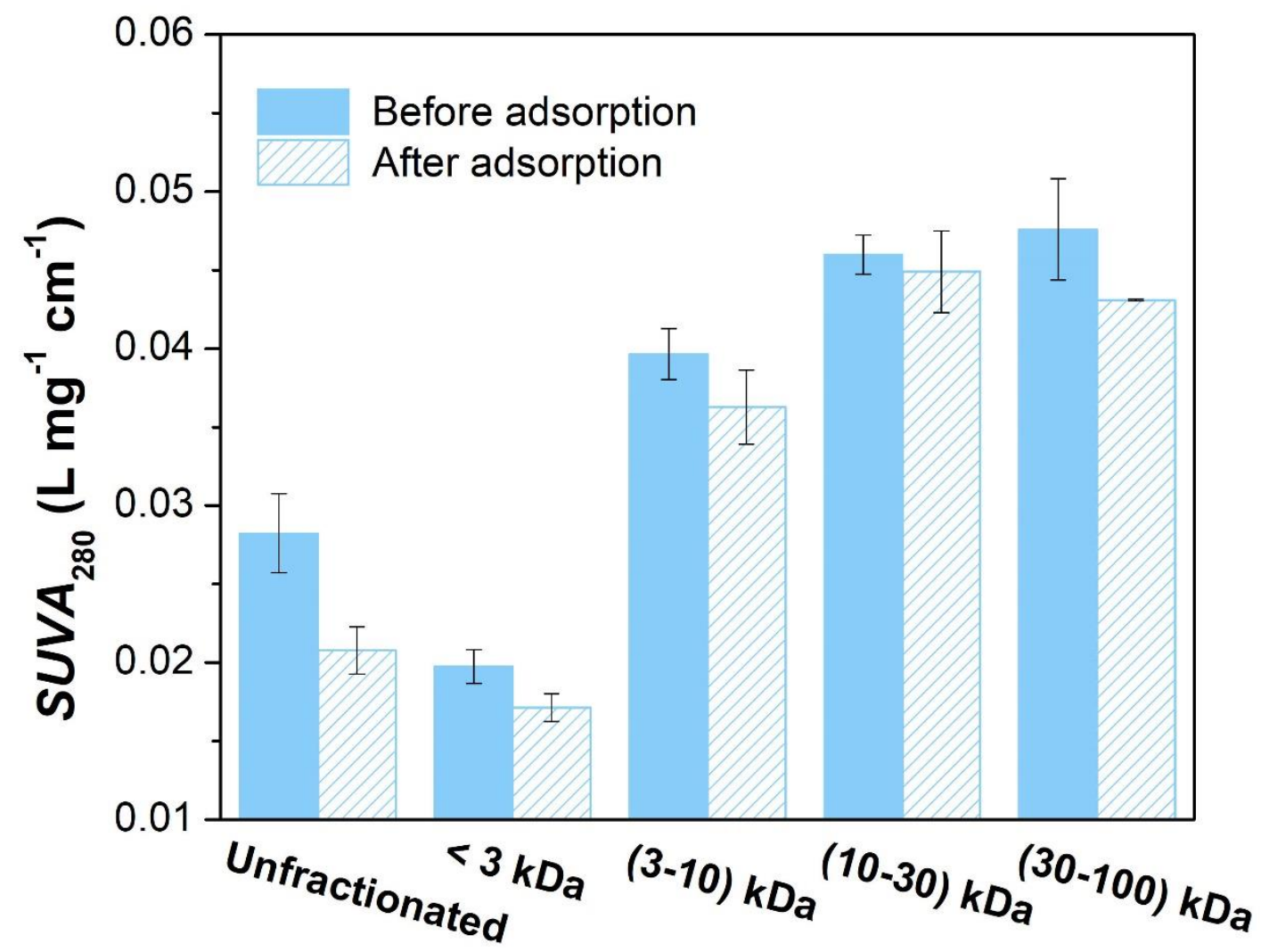

Figure S7. SUVA at wavelength of $280 \mathrm{~nm}$ for dissolved NOM fractions before and after adsorption onto Fh NPs for samples collected from solution containing NOM (initially $10 \mathrm{mg}$ $\mathrm{C} / \mathrm{L}), \mathrm{NaCl}(150 \mathrm{mM})$ and Fh NPs (10 mg Fe/L). Dissolved NOM was separated from Fh NPs using Amicon $100 \mathrm{kDa}$ centrifugal ultrafiltration devices and was compared to control ("before adsorption") containing no NPs and processed the same way. SUVA was obtained by dividing the UV absorbance by the carbon concentration measured by TOC and the $1 \mathrm{~cm}$ path length for the UV cuvette. Error bars represent the standard deviations across $n=2$ samples. 


\subsection{Intensity-mean size of Fh coated with SRNOM}
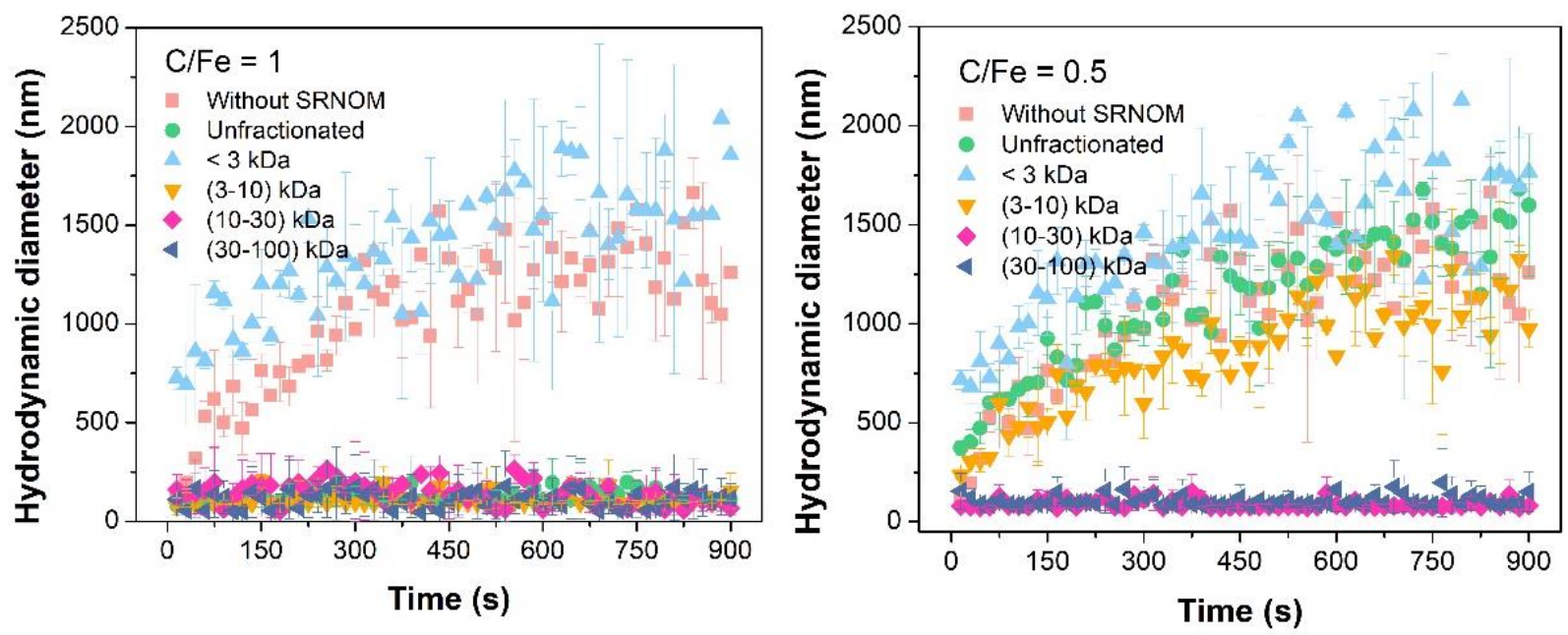

Figure S8 Aggregation kinetic profiles using the intensity-mean diameter from a non-negatively constrained least squares (NNLS) fitting algorithm (Malvern Zetasizer Software v. 7.13) for Fh NPs in $150 \mathrm{mM} \mathrm{NaCl}$ with (a) $\mathrm{C} / \mathrm{Fe}=1$ and (b) $\mathrm{C} / \mathrm{Fe}=0.5$. Error bars represent the standard deviation of $n=2$ samples. 
3.6. Correlation functions for Fh NPs with and without SRNOM

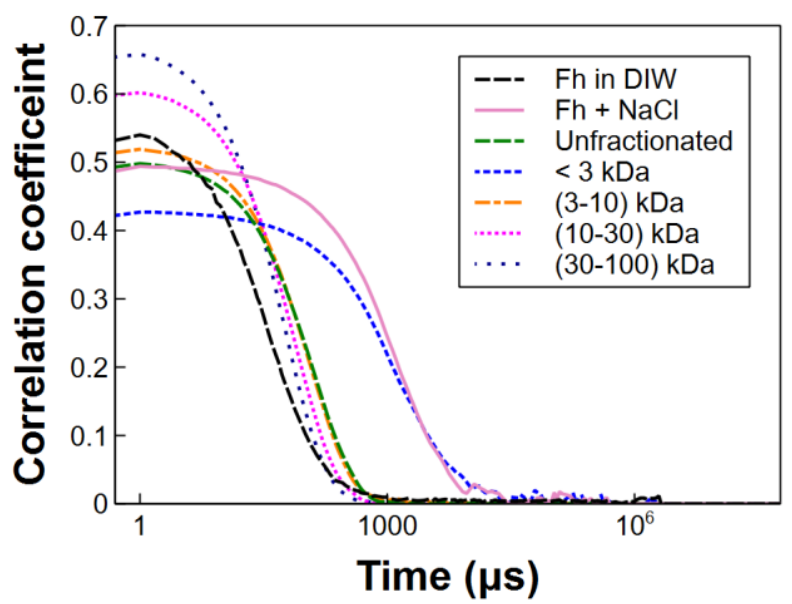

Figure S9. Correlation functions of Fh NPs in DI water, and in solutions with or without different SRNOM fractions in $150 \mathrm{mM} \mathrm{NaCl}$ obtained after 15 minutes. The correlation functions in 150 $\mathrm{mM} \mathrm{NaCl}$ without SRNOM or containing SRNOM $<3 \mathrm{kDa}$ shifts to the right compared to the other correlation functions, indicating aggregation of Fh NPs in these suspensions. 


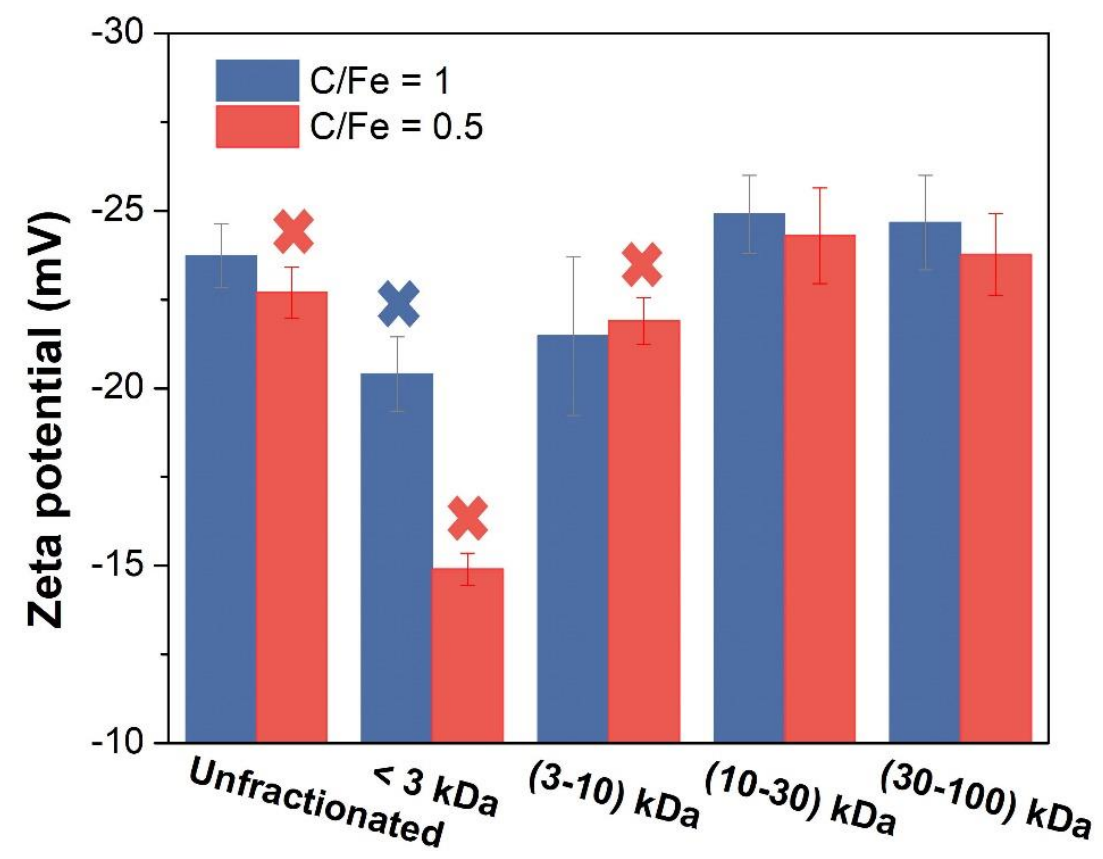

Figure S10. Zeta potentials of Fh NPs after adsorption of unfractionated and fractionated NOM at different $\mathrm{C} / \mathrm{Fe}$ ratios, $\mathrm{R}=1$ and 0.5 . Error bars represent the standard deviations of $n=2$ samples. The cross sign points out samples in which significant aggregation was observed within $15 \mathrm{~min}$. The zeta potential of the Fh NPs without NOM was $+24.8 \pm 1.6 \mathrm{mV}$. 
3.8. NP aggregation and adsorbed mass with $S R N O M_{<3} k D a$ at different $C / F e$ mass ratios

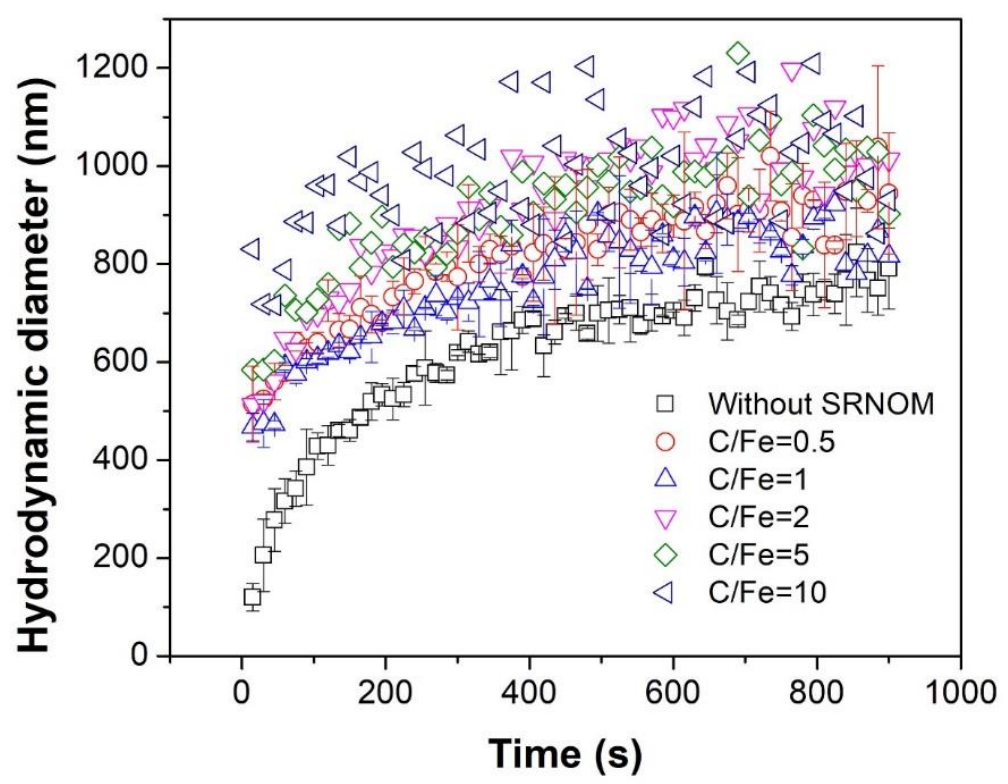

Figure S11. Fh NPs aggregation kinetics in $\mathrm{SRNOM}_{<3 \mathrm{kDa}}$ with different $\mathrm{C} / \mathrm{Fe}$ ratio in 150 $\mathrm{mM} \mathrm{NaCl}(\mathrm{pH}=5.5 \pm 0.2)$. Error bars for $\mathrm{C} / \mathrm{Fe}$ ratio equal to 0.5 or 1 represent the standard deviation of $n=2$ samples. 


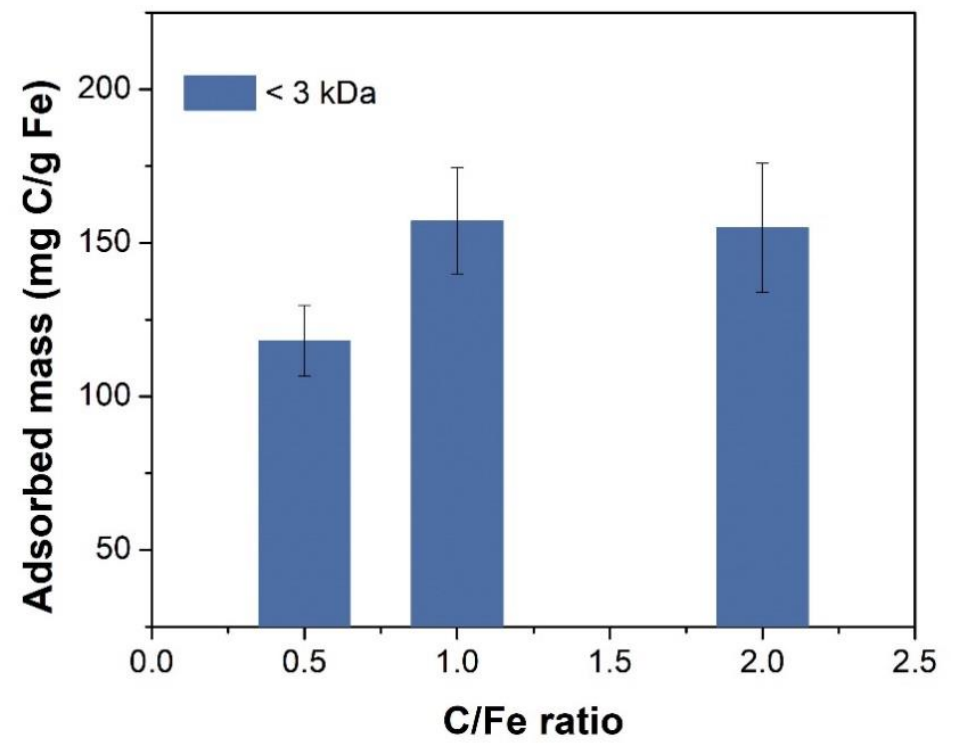

Figure S12. Adsorbed mass for $\mathrm{SRNOM}_{<3 \mathrm{kDa}}$ with different $\mathrm{C} / \mathrm{Fe}$ ratios $(0.5,1,2)$ in $150 \mathrm{mM}$ $\mathrm{NaCl}(\mathrm{pH}=5.5 \pm 0.2)$. Error bars represent the standard deviation of $n=2$ samples. 

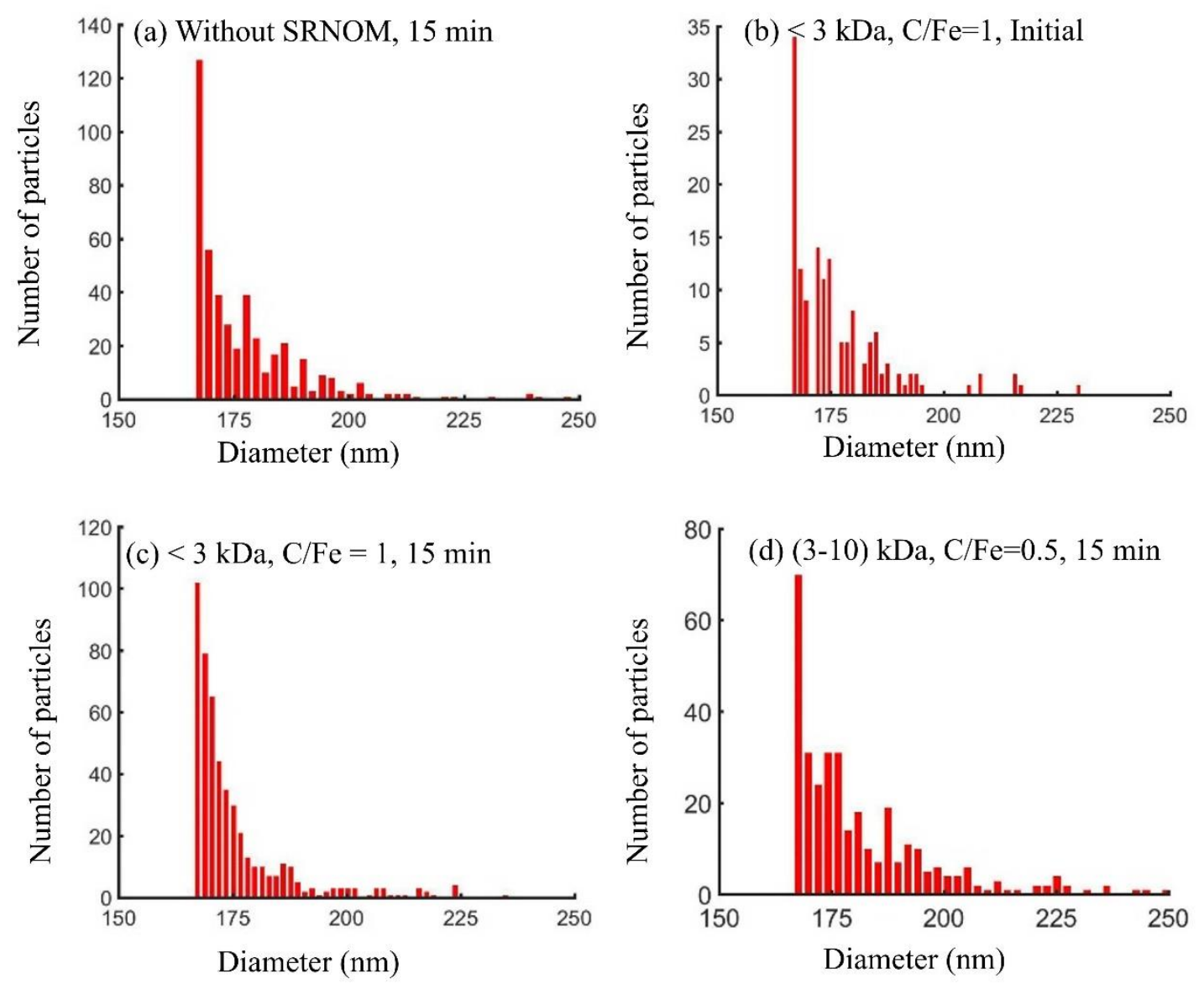

Figure S13. Number-based particle size distributions of Fh NPs using spICP-MS: (a) without SRNOM, after aggregation for $15 \mathrm{~min}$; (b) $\mathrm{SRNOM}_{<3} \mathrm{kDa} \mathrm{C} / \mathrm{Fe}=1$, initial measurement right after mixing solutions; (c) $\mathrm{SRNOM}_{<3} \mathrm{kDa} \mathrm{C} / \mathrm{Fe}=1,15 \mathrm{~min}$; (d) $\mathrm{SRNOM}_{3-10 \mathrm{kDa}} \mathrm{C} / \mathrm{Fe}=0.5,15$ min. By fitting the size distribution curves with lognormal models, the average particle diameters are calculated to be $180 \pm 20,170 \pm 10,180 \pm 20,180 \pm 20 \mathrm{~nm}$ for (a), (b), (c), and (d), respectively. 
Table S2. Comparison of NP or aggregate diameters derived from DLS and spICP-MS measurements.

\begin{tabular}{|c|c|c|}
\hline Sample & DLS (nm) & spICP-MS (nm) \\
\hline Without SRNOM, initial & $120 \pm 30$ & $\mathrm{n} / \mathrm{d}$ \\
\hline Without SRNOM, 15 min & $790 \pm 80$ & $180 \pm 20$ \\
\hline $\mathrm{SRNOM}_{<3 \mathrm{kDa}} \mathrm{C} / \mathrm{Fe}=1$, initial & $470 \pm 30$ & $170 \pm 10$ \\
\hline $\mathrm{SRNOM}_{<3 \mathrm{kDa}} \mathrm{C} / \mathrm{Fe}=1,15 \mathrm{~min}$ & $902 \pm 8$ & $180 \pm 20$ \\
\hline $\mathrm{SRNOM}_{3-10 \mathrm{kDa}} \mathrm{C} / \mathrm{Fe}=1$, initial & $59 \pm 1$ & $\mathrm{n} / \mathrm{d}$ \\
\hline $\mathrm{SRNOM}_{3-10 \mathrm{kDa}} \mathrm{C} / \mathrm{Fe}=1,15 \mathrm{~min}$ & $76 \pm 3$ & $\mathrm{n} / \mathrm{d}$ \\
\hline $\mathrm{SRNOM}_{3-10 \mathrm{kDa}} \mathrm{C} / \mathrm{Fe}=0.5$, initial & $165 \pm 6$ & $180 \pm 20$ \\
\hline $\mathrm{SRNOM}_{3-10 \mathrm{kDa}} \mathrm{C} / \mathrm{Fe}=0.5,15 \mathrm{~min}$ & $750 \pm 20$ & \\
\hline
\end{tabular}

* n/d indicates not detected, as only Fh NPs larger than $134 \mathrm{~nm}$ can be detected by spICP-MS. 


\subsection{Fractal dimensions of Fh aggregates}

The fractal dimensions of the Fh NP aggregates after $\approx 15$ to 30 min without SRNOM and containing SRNOM $<3 \mathrm{kDa}$ were $1.8 \pm 0.1$ and $1.7 \pm 0.1$ (Figure S14). Previously, Amal et al. investigated the aggregation of hematite particles in the presence of Suwannee River fulvic acid by static light scattering and concluded that depending on the concentration of fulvic acid and salt concentration, different aggregate structures can be formed. Their results suggest that during fast aggregation (salt concentration higher than CCC value) and a low surface coverage of fulvic acid, the aggregation process results in non-uniform surfaces charges. Initially, the fulvic-coated nanoparticle aggregates had the same fractal dimension as the uncoated nanoparticles aggregates; then, due to presence of oppositely-charged surface patches, the aggregates rearranged to a more compact form (higher fractal dimension). However, at higher concentration of fulvic acids (with high surface coverage), due to flocculation bridging, open structures are formed. ${ }^{30}$ Similarly, we observed no significant difference between the fractal dimensions for the uncoated and $<3 \mathrm{kDa}$ NOM-coated particles during short time periods after initiating aggregation. Our fractal dimensions $(\approx 1.7$, indicating cluster-cluster aggregation) are consistent with the values reported by the Gentile et al. for ferrihydrite nanoparticle aggregates with dissolved organic matter ${ }^{31}$ but lower than those reported by Amal et al. ${ }^{22,30,32}$ of $>2$ for diffusion-limited monomer-cluster aggregation, possibly because of the higher number concentration of particles used in our study $(\approx$ $4 \times 10^{14}$ particles $\left./ \mathrm{L}\right)$ compared to the Amal studies $\left(\approx 2 \times 10^{13}\right.$ particles $\left./ \mathrm{L}\right)$, as discussed further by Wilcoxon et al. ${ }^{33}$

The similar fractal dimensions for the diffusion-limited aggregates with and without $<3$ $\mathrm{kDa}$ NOM provides orthogonal evidence to support the conclusion from the spICP-MS measurements that the $<3 \mathrm{kDa} \mathrm{NOM}$ induced electrostatic destabilization rather than bridging flocculation, since bridging flocculation should be characterized by lower fractal dimensions compared to electrostatically-destabilized, uncoated NPs. ${ }^{30}$ While an increase in fractal dimension over time as observed by Amal et al. ${ }^{30}$ would be useful to further distinguish a patch charge 
mechanism (leading to restructuring of aggregates to a more compact form). Here we did not observe significant changes in the fractal dimensions within initial 6 hours of measurements, while visible settling of aggregates occurred within 12 hours, preventing data collection for longer duration.

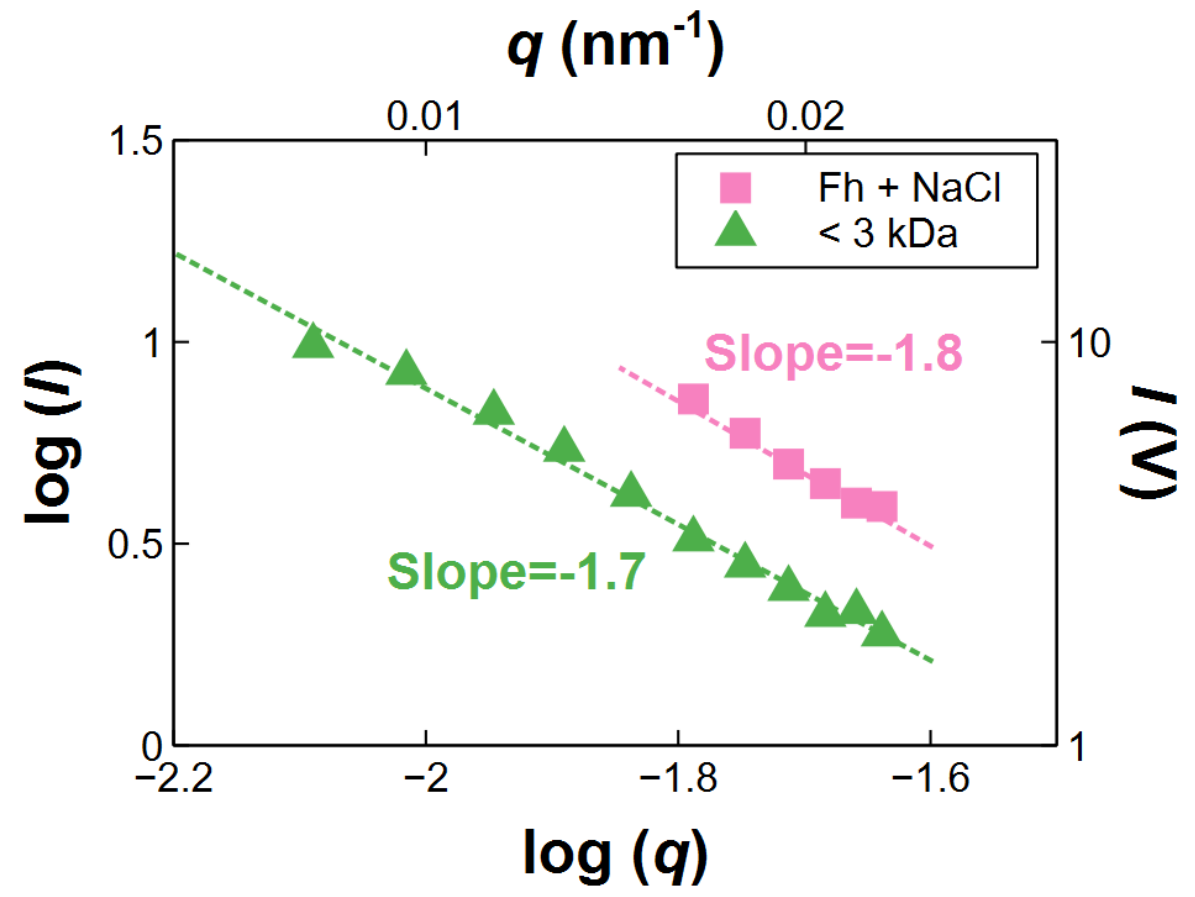

Figure S14. Plot of log scattering intensities versus the log scattering vector to obtain the fractal dimensions of Fh NPs $(10 \mathrm{mg} \mathrm{Fe} / \mathrm{L})$ at $\mathrm{pH}=5.5 \pm 0.2 \mathrm{in} \mathrm{NaCl}$ solution $(150 \mathrm{mM})$ in the absence of SRNOM and in the presence of $\mathrm{SRNOM}_{<3 \mathrm{kDa}}(10 \mathrm{mg} \mathrm{C} / \mathrm{L})$. The secondary $\mathrm{x}$ and $\mathrm{y}$ axis show the value of scattering vector $\left(\mathrm{nm}^{-1}\right)$ and scattering intensities $(\mathrm{V})$, respectively. The average of the slopes (fractal dimensions) over $\approx 10$ minutes of experiment were $1.8 \pm 0.1$ and $1.7 \pm 0.1$ for Fh NPs (10 mg Fe/L) in $\mathrm{NaCl}$ solution $(150 \mathrm{mM})$ in the absence of SRNOM and in the presence of $\mathrm{SRNOM}_{<3 \mathrm{kDa}}$, respectively. 
3.11. Aggregation behavior of Fh NPs at C/Fe mass ratio of 0.2

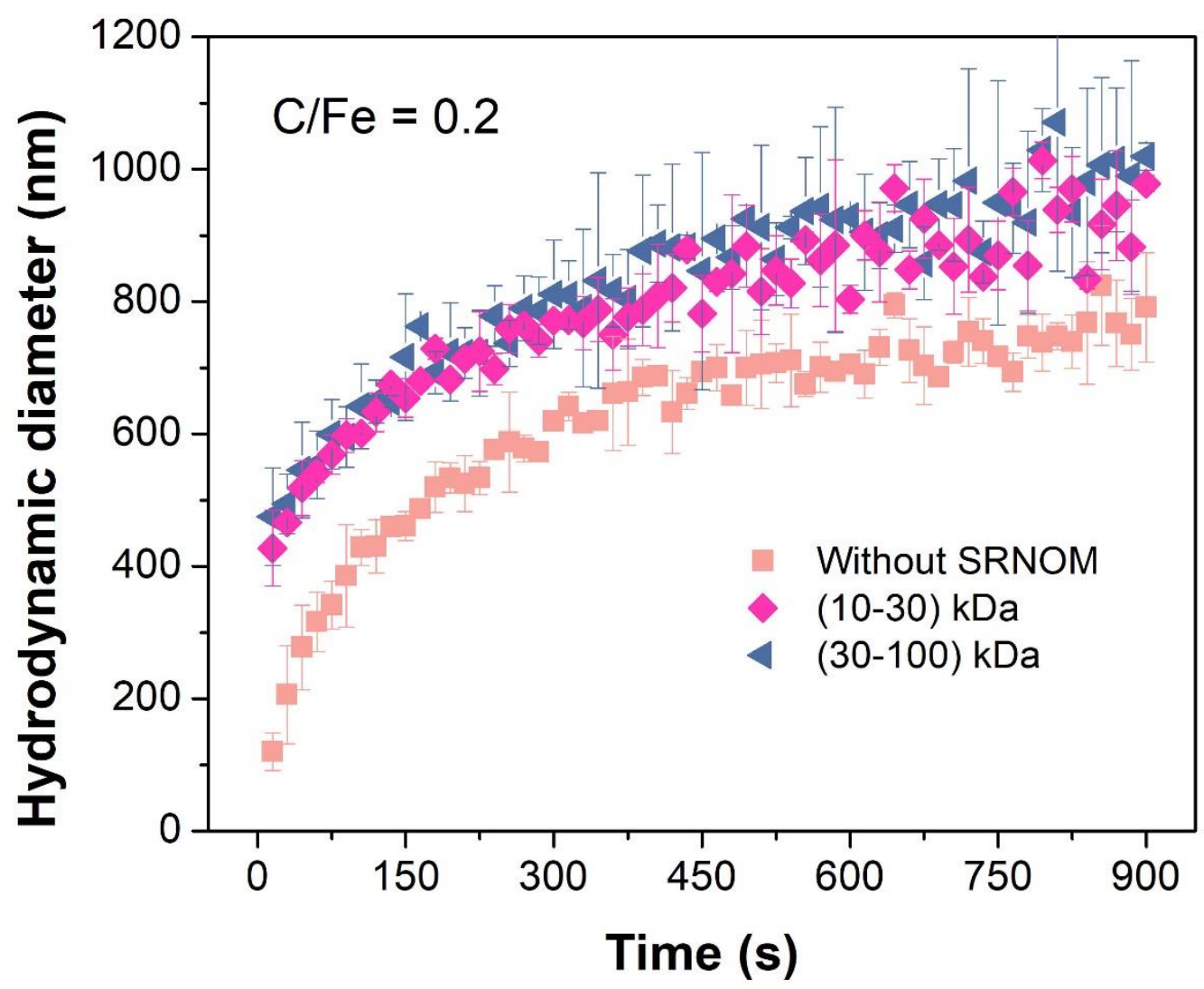

Figure S15. Aggregation kinetic of Fh NPs at $\mathrm{pH}=5.5 \pm 0.2 \mathrm{in} \mathrm{NaCl}$ solution $(150 \mathrm{mM})$ in the absence of SRNOM and in the presence of $\mathrm{SRNOM}_{10-30 \mathrm{kDa}}$ and $\mathrm{SRNOM}_{30-100 \mathrm{kDa}}$ at $\mathrm{C} / \mathrm{Fe}=0.2$. Error bars represent the standard deviations of $n=2$ samples. 


\section{References}

1. Louie, S. M.; Tilton, R. D.; Lowry, G. V., Effects of molecular weight distribution and chemical properties of natural organic matter on gold nanoparticle aggregation. Environ. Sci. Technol. 2013, 47, (9), 4245-4254.

2. Yin, Y.; Shen, M.; Tan, Z.; Yu, S.; Liu, J.; Jiang, G., Particle coating-dependent interaction of molecular weight fractionated natural organic matter: impacts on the aggregation of silver nanoparticles. Environ. Sci. Technol. 2015, 49, (11), 6581-6589.

3. Shen, M.; Hai, X.; Shang, Y.; Zheng, C.; Li, P.; Li, Y.; Jin, W.; Li, D.; Li, Y.; Zhao, J.; Lei, H.; Xiao, H.; Li, Y.; Yan, G.; Cao, Z.; Bu, Q., Insights into aggregation and transport of graphene oxide in aqueous and saturated porous media: Complex effects of cations with different molecular weight fractionated natural organic matter. Sci. Total Environ. 2019, 656, 843-851.

4. Louie, S. M.; Spielman-Sun, E. R.; Small, M. J.; Tilton, R. D.; Lowry, G. V., Correlation of the physicochemical properties of natural organic matter samples from different sources to their effects on gold nanoparticle aggregation in monovalent electrolyte. Environ. Sci. Technol. 2015, 49, (4), 2188-2198.

5. Shen, M.-H.; Yin, Y. G.; Booth, A.; Liu, J. F., Effects of molecular weight-dependent physicochemical heterogeneity of natural organic matter on the aggregation of fullerene nanoparticles in mono- and di-valent electrolyte solutions. Water Res. 2015, 71, 11-20.

6. Zhou, Q.; Ouyang, S.; Ao, Z.; Sun, J.; Liu, G.; Hu, X., Integrating biolayer interferometry, atomic force microscopy, and density functional theory calculation studies on the affinity between humic acid fractions and graphene oxide. Environ. Sci. Technol. 2019, 53, (7), 3773-3781.

7. Tang, Y.; Michel, F. M.; Zhang, L.; Harrington, R.; Parise, J. B.; Reeder, R. J., Structural properties of the $\mathrm{Cr}(\mathrm{III})-\mathrm{Fe}(\mathrm{III})$ (oxy)hydroxide compositional series: insights for a nanomaterial "solid solution". Chem. Mater. 2010, 22, (12), 3589-3598.

8. Li, Z.; Zhang, T.; Li, K., One-step synthesis of mesoporous two-line ferrihydrite for effective elimination of arsenic contaminants from natural water. Dalton Trans. 2011, 40, (9), 2062-6.

9. Liao, P.; Li, W.; Wang, D.; Jiang, Y.; Pan, C.; Fortner, J. D.; Yuan, S., Effect of reduced humic acid on the transport of ferrihydrite nanoparticles under anoxic conditions. Water Res. 2017, 109, 347-357.

10. Liu, J.; Louie, S. M.; Pham, C.; Dai, C.; Liang, D.; Hu, Y., Aggregation of ferrihydrite nanoparticles: effects of $\mathrm{pH}$, electrolytes, and organics. Environ. Res. 2019, 172, 552-560.

11. Shakiba, S.; Hakimian, A.; Barco, L. R.; Louie, S. M., Dynamic intermolecular interactions control adsorption from mixtures of natural organic matter and protein onto titanium dioxide nanoparticles. Environ. Sci. Technol. 2018, 52, (24), 14158-14168.

12. Laborda, F.; Jiménez-Lamana, J.; Bolea, E.; Castillo, J. R., Critical considerations for the determination of nanoparticle number concentrations, size and number size distributions by single 
particle ICP-MS. J. Anal. At. Spectrom. 2013, 28, (8), 1220-1232.

13. Lee, S.; Bi, X.; Reed, R. B.; Ranville, J. F.; Herckes, P.; Westerhoff, P., Nanoparticle size detection limits by single particle ICP-MS for 40 elements. Environ. Sci. Technol. 2014, 48, (17), 10291-10300.

14. Montaño, M. D.; Olesik, J. W.; Barber, A. G.; Challis, K.; Ranville, J. F., Single Particle ICP-MS: Advances toward routine analysis of nanomaterials. Anal. Bioanal.Chem. 2016, 408, (19), 5053-5074.

15. Mitrano, D. M.; Barber, A.; Bednar, A.; Westerhoff, P.; Higgins, C. P.; Ranville, J. F., Silver nanoparticle characterization using single particle ICP-MS (SP-ICP-MS) and asymmetrical flow field flow fractionation ICP-MS (AF4-ICP-MS). J. Anal. At. Spectrom. 2012, 27, (7), 1131-1142.

16. Pace, H. E.; Rogers, N. J.; Jarolimek, C.; Coleman, V. A.; Higgins, C. P.; Ranville, J. F., Determining transport efficiency for the purpose of counting and sizing nanoparticles via single particle inductively coupled plasma mass spectrometry. Anal. Chem. 2011, 83, (24), 9361-9369.

17. Schwertfeger, D. M.; Velicogna, J. R.; Jesmer, A. H.; Saatcioglu, S.; McShane, H.; Scroggins, R. P.; Princz, J. I., Extracting metallic nanoparticles from soils for quantitative analysis: method development using engineered silver nanoparticles and SP-ICP-MS. Anal. Chem. 2017, $89,(4), 2505-2513$.

18. Geertsen, V.; Barruet, E.; Gobeaux, F.; Lacour, J.-L.; Taché, O., Contribution to accurate spherical gold nanoparticle size determination by single-particle inductively coupled mass spectrometry: a comparison with small-angle x-ray scattering. Anal. Chem. 2018, 90, (16), 97429750.

19. Vidmar, J.; Oprčkal, P.; Milačič, R.; Mladenovič, A.; Ščančar, J., Investigation of the behaviour of zero-valent iron nanoparticles and their interactions with $\mathrm{Cd}^{2+}$ in wastewater by single particle ICP-MS. Sci. Total Environ. 2018, 634, 1259-1268.

20. Hadioui, M.; Merdzan, V.; Wilkinson, K. J., Detection and characterization of $\mathrm{ZnO}$ nanoparticles in surface and waste waters using single particle ICPMS. Environ. Sci. Technol. 2015, 49, (10), 6141-6148.

21. Han, L.; Sun, K.; Keiluweit, M.; Yang, Y.; Yang, Y.; Jin, J.; Sun, H.; Wu, F.; Xing, B., Mobilization of ferrihydrite-associated organic carbon during Fe reduction: Adsorption versus coprecipitation. Chem. Geol. 2019, 503, 61-68.

22. Amal, R.; Raper, J. A.; Waite, T. D., Fractal structure of hematite aggregates. J. Colloid Interface Sci. 1990, 140, (1), 158-168.

23. Österberg, R.; Lindovist, I.; Mortensen, K., Particle size of humic acid. Soil Sci. Soc. Am. J. 1993, 57, (1), 283-285.

24. Österberg, R.; Mortensen, K., Fractal dimension of humic acids. Eur. Biophys. J. 1992, 21, (3), 163-167.

25. Österberg, R.; Mortensen, K., The growth of fractal humic acids: cluster correlation and gel formation. Radiat. Environ. Biophys. 1994, 33, (3), 269-276.

26. Xu, F.; Yao, Y.; Alvarez, P. J. J.; Li, Q.; Fu, H.; Yin, D.; Zhu, D.; Qu, X., Specific ion effects 
on the aggregation behavior of aquatic natural organic matter. J. Colloid Interface Sci. 2019, 556, 734-742.

27. Egeberg, P. K.; Christy, A. A.; Eikenes, M., The molecular size of natural organic matter (NOM) determined by diffusivimetry and seven other methods. Water Res. 2002, 36, (4), 925-932. 28. Millipore User Guide: Amicon ${ }^{\circledR}$ Ultra-4 Centrifugal Filter Devices; 2018.

29. Hiemstra, T.; Van Riemsdijk, W. H., A surface structural model for ferrihydrite I: Sites related to primary charge, molar mass, and mass density. Geochim. Cosmochim. Acta 2009, 73, (15), 4423-4436.

30. Amal, R.; Raper, J. A.; Waite, T. D., Effect of fulvic acid adsorption on the aggregation kinetics and structure of hematite particles. J. Colloid Interface Sci. 1992, 151, (1), 244-257.

31. Gentile, L.; Wang, T.; Tunlid, A.; Olsson, U.; Persson, P., Ferrihydrite nanoparticle aggregation induced by dissolved organic matter. J. Phys. Chem. A 2018, 122, (38), 7730-7738.

32. European Biophysics JournalAmal, R.; Coury, J.; Raper, J. A.; Walsh, W.; Waite, T., Structure and kinetics of aggregating colloidal haematite. Colloids Surf. 1990, 46, (1), 1-19.

33. Wilcoxon, J. P.; Martin, J. E.; Schaefer, D. W., Aggregation in colloidal gold. Physical Review A 1989, 39, (5), 2675-2688. 